\title{
Investor Response to Appointment of Female CEOs and CFOs
}

\author{
Eline Brinkhuis ${ }^{\mathrm{a}}$ \& Bert Scholtens ${ }^{\mathrm{b}, \mathrm{c}}$
}

\begin{abstract}
We study the impact of appointing women to top executive positions from an investor perspective. We analyze whether shareholders value announcement of appointment of women to top positions differently than they do appointment of men. This study uses an international sample of 100 announcements of top executive appointments of women who replace men and investigates how shareholders respond to such appointments. This research combines an event study with a matched pair analysis to compare the response from investors regarding appointment of female versus male CEOs and CFOs. We establish that investors do not seem to value appointment of women significantly differently from that of men. This finding suggests that, from the investor perspective, there appears to be no business case for a particular gender when it comes to appointing a CEO or CFO.
\end{abstract}

a Department of Economics, Econometrics and Finance, University of Groningen, PO Box 800, 9700 AV Groningen, The Netherlands

b School of Management, University of Saint Andrews, The Gateway, North Haugh, St Andrews, Fife, KY16 9RJ, Scotland, UK

c corresponding author: phone +31-503637064, email L.J.R.Scholtens@RUG.NL

Keywords: gender diversity; appointment; CEO; CFO; shareholders 


\section{Introduction}

The lack of women in top management positions is a frequently discussed and researched topic in the business community and in the academic literature (Adams 2016). This literature is very diverse regarding theories and methods and the results are quite varying (see Post and Byron 2015). Often, performance and quality differentials between men and women are assumed to be behind the lack of equal female representation; reducing inequality is also thought to come at a cost (Bohnet et al. 2016; Golding 2014; Niederle et al. 2013). Others argue that a cultural gender bias causes the imbalance, thereby excluding talented people (Abdullah et al. 2016; Adams and Funk 2012; Hillman et al. 2002). Until recently, the focus of most of this research was on the role of women on boards, but there has emerged a new strand of literature that studies gender at the executive level as well (Dezsö et al. 2016; Faccio et al. 2016; Huang and Kisgen 2013; Kahn and Vieito 2013; Wang and Kelan 2013). The majority of studies on gender and firm performance rely on accounting data and focus on how firms respond to the presence of female executives. However, these studies usually disregard the investor perspective. One problem with most of this literature is that it is endogeneity-plagued, meaning that the decision to appoint a female board member need not be independent of firm characteristics or that both may be determined by hidden or omitted variables (i.e., explanatory variables may correlate with error terms).

This study adds to the literature by investigating the role of gender at the top executive level from a shareholder perspective. Shareholders have incentives to thoroughly assess the potential impact of all types of news on firm equity value. Stock price reactions summarize expected changes in firm performance for all future dates. In our view, the forward looking perspective of the shareholder provides a highly relevant framework to study the role of gender in firm stock-price performance. Ahern and Dittmar (2012) focus on the stock price response to mandatory increases in female board representation. Our study focuses on the leading executive positions on the board. Thus far, perception of perceived suitability of men and women has been studied mainly experimentally. For example, Haslam and Ryan (2008) report experimental investigations among management graduates, high school students, and business leaders. We investigate, on the basis of stock market data, investor 
perception regarding announcement of appointment of female top executives replacing males. We rely on the notion of market efficiency, which assumes that stock markets reflect the fundamental value of a listed firm, that is, the discounted sum of all expected future cash flows (i.e., the in-equilibrium perspective of markets, Demsetz 1983). From this perspective, only unexpected information can impact firm value, but not all such information need be actually value relevant. This notion is at the heart of finance theory (Demsetz 1983; Fama 1970, 1991, 1995; Jensen 1978).

We investigate whether the announcement of appointment of a female CEO or CFO is followed by a response that is significantly different from announcement of appointment of a male top executive. Efficient market theory posits that if shareholders deem female representation beneficial, they will place a higher value on the firm. However, if shareholders believe that female representation worsens firm performance, which would reflect the view that the current situation of underrepresentation is optimal, they will lower firm valuation. Given these contrasting perspectives, the issue of which view actually holds is an empirical matter. Ideally, we could also establish what drives any such differential. Unfortunately, the sample does not contain enough observations to allow for a more structural approach (see Athey and Imbens 2017).

This study investigates the positions of CEO and CFO, as they are the most important positions in a firm in that they are responsible for overall strategy and performance and usually are the "face" of the firm in relation to stakeholders and society. While the impact of the CEO on firm performance is substantial, it is also contingent on other key executives (see Carpenter and Sanders 2002; Hambrick 1995); CFOs are critical in this respect, especially following introduction of the Sarbanes-Oxley Act of 2002 (Chava and Purnanandam 2010; Gore et al. 2011).

Our empirical strategy is to combine the event study methodology with a matched pair analysis to determine whether investors indeed respond differently to a female top executive appointment than to a male appointment. The results are of particular interest to investors, existing boards, and to recruiters for corporate boards, since this study is an empirical test of the notion that female CEOs and CFOs are “costly” (or not) from an investor perspective. From a societal 
perspective, the study is relevant in that it sheds light on the value relevance of gender in top executive positions.

The remainder of this paper proceeds as follows: First, we review the literature and present our hypotheses. We then detail methods to test our hypotheses and introduce the data. Next, we present and discuss our results. Finally, we summarize our findings and set forth our conclusions.

\section{Background and Hypotheses}

This section discusses the study background and introduces the hypotheses. The focus is on the literature regarding financial market performance and CEO turnover, then the literature on gender and boards, and finally on the literature on gender of top management and firm stock market performance. Then, our hypotheses are articulated.

One strand of the literature addresses CEO turnover and stock market response. Investor reaction to CEO or management changes in general are widely investigated, but the results are mixed. Weisbach (1988), Denis and Denis (1995), Huson et al. (2004), and Pessarossi and Weill (2012) find positive market reactions to (forced) CEO turnover announcements. However, Reinganum (1985), Beatty and Zajac (1987), Warner et al. (1988), and Niño and Romero (2007) find no significant response. Further, Dedman and Lin (2002) establish that markets react negatively to CEO turnover announcements. A widely acknowledged problem is that the event of the announcement of a new CEO is usually confounded by that of the withdrawal of the old CEO. Financial market analysis is not suitable to disentangling the impact on firm equity value of this type of news. As such, it is not possible to separate investor response regarding these two aspects. There is a closely related literature on the background of the new CEO. In this respect, the distinction between insider and outsider is highlighted (e.g., Furtado and Rozeff 1987; Johnson 1996); usually, appointment of an insider as new CEO is more highly valued than appointment of an outsider.

The gender differences literature relies predominantly on the governance perspective, is usually concerned about fairness issues, and investigates the role of gender mainly at the board level (Adams 2016; Adams and Ferreira 2009; Adams and Funk 2012; Bernardi et al. 2012; Haslam and 
Kisgen 2008; Post and Byron 2015; Terjesen et al. 2009). The key notion here is that female directors bring different skills to the board. Board diversity may improve skill complementarities of the board as a whole (Anderson et al. 2011). In particular, women are regarded as being more risk-averse, less overconfident, and more sensitive to social signals in determining appropriate behavior (Croson and Gneezy 2009). Differences in talents, perspectives, and behavior between men and women, among many other factors, can affect the ability to monitor and discipline corporate managers (Hillman et al. 2002). Post and Byron (2015) perform a meta-analysis of the literature on women on boards and firm performance. These authors review 140 studies and find that female board representation is positively associated with accounting returns, especially in countries with strong shareholder protection. One concern with this research is that the identification strategy does not clearly rule out that the choice of a female board member is related to particular board or firm characteristics.

Another strand of literature consists of stock market performance studies regarding gender in relation to boards and top management. Post and Byron (2015) find that the relationship between female board representation and market performance is positive but not statistically significantly different from zero. Based on the results from more than 70 studies, Post and Byron (2015) find that female board representation is not significantly related to market performance. These authors also find that the mean effect size associated with female board representation and market returns is significantly lower than the mean effect size associated with female board representation and accounting returns. Most studies in this strand of literature focus on gender and boards. For example, Ahern and Dittmar (2012) find a negative impact on stock market returns from announcement of a mandatory increase in female board representation in Norway. Chapple and Humphrey (2014) find weak evidence of a negative correlation between multiple women on the board and market performance. In contrast, Campbell and Mínguez-Vera (2008) find that investors do not appear to penalize firms that increase the number of female board members, and Francoeur (2008) finds that there is no statistically significant performance difference between firms with high and low female board member representation. Regarding top executives, Lee and James (2007) closely relates to our work. These authors study top management team announcements in the US from 1999 to 2000, which 
included 17 announcements of female CEO appointments. They find that cumulative abnormal returns are significant for both male and female appointments. Lee and James (2007 p. 239) predict that “as women executives becomes less unique, there will be less difference in the reaction to the announcement of male appointments and female appointments.” These authors also show that investors react significantly more negatively to announcement of female CEOs than they do to announcement of male CEOs. This finding contrasts with results from studies about gender and boards that rely on accounting measures (see Post and Byron 2015). Adams (2016) is highly critical of research on female representation on boards and in top management. This author reflects particularly upon the weaknesses of the data (definitions, small sample sizes, sample selection) and the theory (especially causal inferences made) and calls for more research. The issue of endogeneity plays a particular role and is difficult to solve, due to the research designs in most of this literature (see also Antonakis et al. 2014).

To complement these strands of the literature, this study first investigates the investor response regarding announcement of appointment of a new top executive. It researches the reaction of the total sample, consisting of both male and female appointments, by testing whether there is an abnormal stock market return following announcement of the appointment of a CEO or CFO. This also is done for the presence or absence of confounding information in the press bulletin that appears with the announcement; when firms produce such information, this could impact their stock returns. We hypothesize that the stock market reaction is more pronounced when such information is announced in the event window. Further, since the literature shows that insiders are valued more positively than outsiders, we expect that there is a more positive (less negative) reaction to the appointment of an outsider than to that of an insider. In addition, it is of interest whether the response to CEO appointments is stronger than those for CFO appointments, assuming that the CEO position is regarded as the most important function in the company. Further, this research extends the predominantly single-country studies to an investigation of the international setting using a sample with observations from 15 industrialized countries. 
More importantly, based on the gender-role stereotyping hypothesis of Lee and James (2007), we expect a statistically significant difference in stock price reaction between announcement of appointment of female and male CEOs or CFOs. Therefore, the main hypothesis is as follows: Stock market return reaction after announcement of appointment of a female CEO/CFO is less strong than that following announcement of appointment of a male CEO/CFO. In all cases, the null hypothesis is that there are no statistically significant differences.

\section{Materials and Methods}

This research combines the event study approach with matched pair analysis to answer the research question. This section briefly explains the background of the event study methodology. It then discusses the endogeneity problem, sampling, and selection of matches.

Event studies examine the short-term price behavior of securities around specific events (Binder 1998). Fama et al. (1969) find that stock markets are (semi-strong) efficient given the rapid adjustment of stock prices to a particular event. Event studies cannot be used to make inferences about causality. To this extent, alternative approaches are available (see Antonakis et al. 2010, 2014). However, we do not pursue these, as our objective is confined to assess whether there actually is something going on. Further, although our sample of female top executives is more than five times that of Lee and James (2007), it is nevertheless too small to employ sound statistical methods that would find determinants of any out- or under-performance. Note that even the event study can be affected by endogeneity problems if the decisions of the firms appointing either a male or female top executive are driven by some unknown underlying variable. Therefore, several sensitivity tests are conducted.

Event studies are rooted in efficient market theory. Fama (1995 p. 76) states that “[...] in an efficient market, at any point in time, the actual price of a security will be a good estimate of its intrinsic value [...].” A more general definition is provided by Jensen: “A market is efficient with respect to information set $\theta_{t}$ if it is impossible to make economic profits by trading on the basis of information set $\theta_{t}$ ” (Jensen 1978 p. 96). Realization of the information set may change over time, but 
no systematic economic profits can be made for any realization of this information set. The implication here is that whatever news is announced, investors will immediately incorporate its effect into the stock price; thus, the market is semi-strong efficient. In this case, there can be abnormal returns (in contrast to the case of strong market efficiency, where all information is known).

Hermalin and Weisbach (1998) find that when investors are forward looking, turnover is more sensitive to accounting measures of performance compared to financial market measures. Hermalin and Weisbach (2003) argue that firms decide allocation of resources to governance and production simultaneously. Then, unless the dependency on common determinants is accounted for, the estimates of the association between governance and performance might be biased. This finding aligns with the view of Cook (2008) on how to account for news in financial markets. However, Cornelli et al. (2013) point out that corporate governance arrangements are a black box. Governance seems to be an unobservable variable usually measured by proxies assumed to correlate with the "true” but unobservable latent variable (Cornelli et al. 2013). By focusing on a very visible variable, namely gender, it might be possible to advance this debate. Of course, gender is just one aspect of governance and must not be viewed as a proxy for all arrangements. Stock market information is used, as this study concentrates on shareholder perception and not on firm performance in general. However, there can be a price reaction even in the absence of agency problems. For example, consider a female CEO unexpectedly replacing a male CEO with poor skills rather than a male CEO who makes poor management choices on purpose (as suggested in agency theory). In this case, it is likely that shareholders respond to this positive news with increased demand for the stock.

The date on which the press release naming the top executive’s appointment is published by the particular company is used as the event day $(\tau=0)$. To arrive at the expected stock market returns, we rely on the market and risk adjusted returns model (the market model) (MacKinlay 1997). There is a window before the announcement to estimate the expected return, and then these expected returns are confronted with the actual returns in the event window (the differential is the abnormal return). Returns $\left(R_{i, t}\right)$ are calculated as: 
$R_{i, \tau}=\ln \left(P_{i, \tau} / P_{i, \tau-1}\right)$

where $P_{i, \tau}$ and $P_{i, \tau-1}$ are the share prices of firm $i$ at the end of period $\tau$ and $\tau$-1, respectively. This study relies on the return index of the firm to account for dividend payments and share repurchases. Abnormal return is the difference between actual return and normal (expected) return. In line with the literature (e.g., Pessarossi and Weill 2012), the estimation window within this study is set at [-160;-3]. Announcement of the appointment of the new CEO/CFO is at the event day (day 0). It is assumed that a response from market participants to the news about the appointment decision is tractable in the event window only. The sample is checked for potentially well-established confounding events like earnings warnings, stock splits, and divestiture/M\&A rumors and announcements in the event window. The returns from the two days immediately before and after the announcement are added to the return on the announcement date itself to gauge the event's total price impact. One issue is whether closer assessment of the impact would be preferable. Most stock exchanges require firms to produce value-relevant information (such as CEO turnover) outside trading hours. Therefore, the day is the best unit to determine the impact of this type of news (Brown and Warner 1985). Further, the estimation window and event window perfectly align in our case.

Estimates of daily abnormal returns (ARs) for firm $i$ at day $\tau$ can be derived using the following equation:

$A R_{i, \tau}=R_{i, \tau}-\alpha_{i}-\beta_{i} * R_{m, \tau}$

where $R_{m, \tau}$ is the return of the (national) stock market index at day $\tau$. $\alpha$ and $\beta$ are parameters in the market model; $\alpha$ is the intercept term and $\beta$ is systematic risk. Firm returns are related to those of the domestic stock market with respect to idiosyncratic risk (see Campbell et al. 2010). Average abnormal returns (AARs) are obtained by dividing the sum of the ARs by the number of events $(N)$ :

$A A R_{\tau}=\frac{1}{N} \sum_{i=1}^{N} A R i, \tau$

MacKinlay (1997) argues that event studies should make use of cumulative abnormal returns (CARs) when there is uncertainty about the exact date at which the information is incorporated in the 
share price. Hence, the use of CARs is in line with the choice for a multiple-day event window. In this study, the windows $[2 ;+2],[-1 ;+1]$ and $[0,+1]$ are analyzed. Cumulative average abnormal returns (CAARs) are calculated by taking the average of the individual CARs; CARs are calculated as follows:

$C A R_{i[\tau 1, \tau 2]}=\sum_{\tau 1}^{\tau 2} A R i, \tau$

Both parametric and non-parametric tests are employed to determine significance. The first is a standardized cross-sectional test by Boehmer et al. (1991). It is robust to mis-specification due to event-induced variance changes. The tests for AARs and the CAARs according to the standardized cross-sectional test are done in line with the calculations applied by Campbell et al. (2010). In addition, Corrado's non-parametric rank test is used (Corrado 1989). The calculations for testing AARs are in Appendix A. Testing for CAARs is done using the same calculations as testing for AARs, but security-event $i$ 's mean rank $(K)$ across the days of the cumulative window is substituted in place of $K_{i, 0}$ and the standard deviation $(S(K))$ is divided by the square root of the number of days in the cumulative window (see Campbell et al. 2010).

The data are obtained from various sources. First, a representative number of press releases of appointments of female CEOs/CFOs was assembled. The Orbis Database was used to find firms announcing appointment of a female CEO/CFO and to collect information on firm sector, size, and location. We selected all announcements regarding the appointment of female CEOs and CFOs between January 2004 and March 2014. All appointments selected concern replacement of a male top executive by a female. Further, we check whether there is a listing on a stock exchange, information about the name of the CEO/CFO, the exact date of the announcement, the industry the firm is in, and the location of its headquarters. Stock return information of the particular firm's stock and the corresponding market index (the prevailing national stock market index of the country where the announcing firm was headquartered) are obtained from Datastream. Afterwards, the announcement dates of these female executives were determined by searching for the corresponding press release on the company website as well as the function (CEO or CFO), whether the executive was an insider, and whether other relevant information was announced during the event window. In this case, 'relevant' is 
defined as a press release covering the announcement of other executives or board members and as a press release related to financial issues, such as financial results and dividend declarations. The next step was to find matched pairs regarding announcements of appointments of female CEOs/CFOs. Announcements of male appointments (male CEOs/CFOs replacing another male top executive) are matched to announcements of female appointments as CEO/CFO using three matching criteria: size, industry, and announcement date. Size is measured as total assets, where we allow a range of $30 \%$ for the size of the match. The list of events and matches (see Appendix B) shows that the size criterion is met in all matches. In cases where the industry criterion is not met, the closest industry is chosen. Further, we investigate the international perspective and analyze whether performance might be related to cultural issues (Ioannou and Serafeim 2012). The study uses the Gender Gap Index of the World Economic Forum to arrive at scores and ranks of the countries in which the firm is headquartered (see Appendix C).

The data collection process results in 105 announcements of female appointments in 15 countries for the period 2004/1-2014/2. From this data set, five announcements are removed because of confounding events (stock splits, M\&A announcements/divestitures, and earnings warnings) in the event window. Our final list of announcements consists of 100 announcements of female appointments and 100 matched announcements of male appointments. Two announcements took place on a Sunday (non-trading day); for these announcements, the next trading day is used as the event day.

Table 1 presents an overview of the main characteristics of the data set. Regarding the size of the 200 companies involved (see Panel A), the table shows total assets of the average firm in the sample at USD 33.7 billion (median is 4.0 billion), operating revenues over assets at $111 \%$ (median 82\%), and number of employees at 24,447 (median 6,000). As to industry composition, Panel B shows that most announcements were in consumer goods, manufacturing, and other industries. Most announcements occurred in the second half of the period under investigation. As to the international dimension, most announcements were in the US. An overview of key properties of the AARs in the estimation window regarding the stock market response to turnover announcements is in Appendix D. It shows the results of the total sample (male and female appointments combined) and of female and 
male appointments separately. We establish that the alfas are not significantly different from zero and that the betas are not significantly different from one. However, the betas for the sample of female CEO and CFO appointment announcements are slightly lower than those of the male appointments. This difference, however, is not statistically significant.

\section{[Insert Table 1 here]}

\section{Results}

This section reports and discusses the results of our analysis with respect to the sample of announcements of male and female CEO/CFO appointments. First, the results of the main analysis are presented and then those of the sensitivity analysis.

\section{Main results}

Table 2 presents the results of the AAR for the total sample, consisting of 100 female and 100 male appointments. The table shows a sign switch at the event day compared to the previous day. There is a negative $A A R$ at the event day as well as on the first day after the event day. However, none of the reported ARs is statistically significant. Hence, the null regarding our first hypothesis cannot be rejected. Therefore, in contrast to, for example, Bonnier and Bruner (1989), but in line with Niño and Romero (2007) and Warner et al. (1988), our results suggest that there are no statistically significant abnormal stock market returns following announcement of appointment of a top executive. As a consequence, it seems that there is no (equity) value relevance in this particular news (see Fama 1970). This does not mean that there is absence of information, but that the information is not deemed value relevant by investors.

\section{[Insert Table 2 here]}

Next, we turn to the main hypothesis regarding the differential in the response to an announcement of the appointment of a man or woman as CEO/CFO. The results of the differences in AARs between female and male appointments are provided in Table 3. The difference is calculated as the $A A R$ of the female appointment minus the $A A R$ of the matched male appointment. Again, there is a 
sign switch at the event day. The test statistics suggest that the ARs are not statistically significant, except that the parametric test shows a marginally significant $A A R$ at day $\tau=2$. Because of this weak significance level and the fact that the Corrado test suggests insignificance, we conclude that the null hypothesis of no difference between the appointment announcement of female and male top executives cannot be rejected. Thus, in contrast to Lee and James (2007), our study finds that there is no statistically significant difference in stock price reaction after announcement of appointment of a female $\mathrm{CEO} / \mathrm{CFO}$ compared to that of a male CEO/CFO. As a consequence, investors do not seem to differentiate in the valuation of the company upon appointment of a female CEO/CFO or a male CEO/CFO. This result is consistent with the findings in Post and Byron (2015), which depart from the shareholder perspective, but it contrasts with studies relying on accounting data (i.e., taking the firm perspective) in the case of gender and boards. The difference with Lee and James (2007) might be due to the fact that our study relies on a much larger sample (more than five times) of female top executive announcements. Further, our sample includes a time period for which investors have gained more experience with female CEOs and CFOs.

\section{[Insert Table 3 here]}

Next, the performance of firm stock over the event window is investigated. The results for three cumulative event windows are shown in Tables 4 and 5. Table 4 shows the CAARs of appointments for the total sample, consisting of 100 female appointments and 100 male appointments. Table 5 shows the difference in CAARs between female appointments and their matched male appointments. Again the difference is calculated as ARs from a announcement of female appointment minus ARs from the matched announcement of male appointment. The CAAR for the $[0 ;+1]$ window is negative in both the total sample and in the "difference sample.” But these negative returns are not statistically significant. Hence, it can be concluded that there are no statistically significant differences between the announcement of a new female or male CEO or CFO. As a consequence, the null hypothesis of no difference cannot be rejected. Therefore, for the cumulative windows as well, we conclude there are no abnormal stock market returns following announcement of appointment of a female CEO/CFO compared to a male CEO/CFO. 
[Insert Tables 4-5 here]

\section{Robustness}

We use sensitivity analysis to arrive at a proper notion of the robustness of the main results. More specifically, four aspects are investigated: the role of confounding information, the appointed CEO/CFO being an insider or an outsider, the appointment relating to either the CEO or the CFO, and the international (cultural) dimension.

The first sensitivity analysis focuses on the presence of potentially relevant additional information. Relevant information release relates to the press release accompanying the announcement covering announcement of other executives or board members and to financial issues, such as financial results and dividend declarations. This type of information presented could bias the ARs reported in the event window, because it is not clear to what information investors react. Non-relevant press releases do not include such information. It is expected that the stock market reaction is stronger when relevant information is announced during the event window. ${ }^{1}$

The second sensitivity analysis addresses the insider/outsider distinction. Furtado and Rozeff (1987) and Lee and James (2007) find that insiders are valued more positively by investors than outsiders. It is therefore expected that the stock price reaction to appointment of an insider is more positive (less negative) than the reaction to appointment of an outsider.

The third sensitivity analysis focuses on whether the announced executive is going to be either the CEO or the CFO of the company. Lee and James (2007) already make a distinction between CEO and other top management team appointments. Compared to CEO appointments, their results show weaker and even insignificant CAARs for top management team appointments. The hypothesis here is that the CEO may be seen as a more important function than the CFO. Therefore, it may be expected

\footnotetext{
${ }^{1}$ In addition, as suggested by one of our reviewers, we accounted for the firms' prior performance. To this extent, we compared the abnormal returns in the event window of firms with the $25 \%$ highest and those with the $25 \%$ lowest performance in the estimation window. This shows that the mean and standard deviation of the abnormal returns in the event window of both groups were about the same (i.e., CAAR [-2;2] of firms with the $25 \%$ lowest performance in the estimation window at 0.00077 versus that with the $25 \%$ highest performance at -0.00041 ), and that the lowest $25 \%$ had slightly lower positive skewness and more kurtosis.
} 
that the stock price reaction after appointment of a CEO is more pronounced than that after appointment of a CFO.

These three analyses were performed for the overall sample of 200 appointments for the [0;+1] cumulative window, and the results for the three pairs of subgroups were compared with an ANOVA to test for differences. The results of the sensitivity analyses are provided in Appendix E, Panels A-C respectively. This appendix shows that there are no statistically significant results for the sensitivity analyses employed in our study. Panel D of Appendix E reports the results of differences tests regarding the two subgroups in all three cases (namely additional relevant news, insider/outsider, and CEO/CFO). This panel shows that there is no significant difference between the subgroups in all three instances and suggests that there seems to be no difference in CAARs when relevant information is announced through press releases in the event window, whether the new CEO/CFO is an insider or not, and whether the appointment of a CEO or a CFO is announced. This finding is in line with the main results of this study.

The fourth sensitivity analysis addresses the international dimension of our sample. To this extent, we use the scores from the World Economic Forum regarding the Gender Gap Index (see Appendix C). The index scores represent gender inequality. In this respect, it might be the case that distrust of a female CEO or CFO is greater in countries with greater inequality, as represented by a lower rank and score on the Gender Gap Index. In the sample, gender inequality is smallest in Finland (rank 2; score 0.845) and largest in Greece (rank 92; score 0.680). The weighted average rank of the sample is calculated, where the weights are based on the number of announcements. This yields an average weighted rank of 34, which happens to be the score of Luxembourg on the Gender Gap Index. Therefore, the announcements from Luxembourg are removed from the comparison of countries scoring relatively high or low on the Gender Gap Index. To be specific, the Gender Gap Index shows that Austria, Greece, Italy, and the US have scores below the weighted mean of the index (i.e., these countries are perceived as having relatively more gender inequality). Therefore, these countries are in the subsample labelled HIGH. Announcements from all other countries, except Luxembourg, are labelled LOW. Further, there is a comparison of the responses to US and non-US announcements of 
appointment of a female CEO or CFO, as the US makes up more than half the total sample and because Lee and James (2007) rely on US data only.

The results of the international analysis are shown in Appendix F. Panel A compares the responses in the subsamples of countries to all announcements. This panel shows that in countries with relatively high scores on the Gender Gap Index, there is a slightly more pronounced (positive) response from the stock market to turnover announcements than in countries with a low score on the index. For the US, the response is slightly more pronounced than elsewhere (but not on days -2 and -1 in the event window). Next, Panel B presents a comparison of the stock market response to the announcement of male CEOs and CFOs. This panel shows that there are no substantial differences between the subgroups. Panel C compares responses to announcements of female top executives. From this panel, we conclude that the response in countries with a relatively high rank on the gender inequality index, as well as the response in the US, is more positive than the response in countries ranking low on the gender inequality index and outside the US, respectively. However, the responses themselves are not statistically significantly different from zero in each of the subgroups. Therefore, it can be concluded that there is some international heterogeneity regarding the response to female appointment but that relevant subsamples (i.e., performing relatively high or low on the Gender Gap Index and US versus elsewhere) do not show statistically significant ARs. This finding contrasts with the findings of Ahern and Dittmar (2012) for boards, but confirms the main findings of our paper. Panel D confirms the overall conclusion inferred from the previous three panels—namely that stock market participants seem to respond more strongely and more positively to announcements of female top executives in countries that rank high on the gender index, as well as in the US, than to those elsewhere, but that there is no statistically significant response to (differences in) gender with such announcements. This conclusion is in line with Post and Byron (2015), who also did not come across significant international differences.

We conclude that there are no statistically significant differences between the stock market responses to female versus male $\mathrm{CEO} / \mathrm{CFO}$ appointments. We establish that, from an investor perspective, it does not matter whether a man or a woman is appointed to the board of directors as a 
CEO or CFO. This result contrasts with studies that find positive effects from female executive tenure and firm financial performance (Deszö et al. 2016; Faccio et al. 2016; Huang and Kisgen 2013; Kahn and Vieito 2013; Wang and Kelan 2013), but is in line with the predictions of Lee and James (2007) and the findings of Campbell and Minguez-Vera (2008) and Francoeur (2008). Our conclusion is reminiscent of the analysis of Hermalin and Weisbach (1998). These authors argue that stock prices reflect not only the present, but also the future, which implies that abnormal stock prices can underestimate the effect of an announced turnover change on firm performance. However, shareholder response is a genuine reflection of shareholder perception about the impact of an (unexpected) announcement regarding the equity value of a firm.

\section{Discussion and Conclusion}

This study investigates the impact of the unexpected announcement of appointment of female CEOs and CFOs on the equity value of firms. Most of the literature on gender and performance thus far investigates the impact of female board membership on performance by using accounting information. In contrast, our focus is on the response of shareholders. This study assumes semi-strong market efficiency, which holds that market participants account for all relevant information in pricing financial assets. As such, unexpected news will be followed by significant changes in stock market returns only if it is deemed value-relevant. If the news does not affect stock market returns, it seems to be irrelevant to firm valuation according to shareholders.

We study announcements of 100 female CEO/CFO appointments in 15 countries over the period 2004-2014 and match these with announcements of appointments of male CEOs/CFOs. All new appointments replace males. For the overall response to announcement of a CEO/CFO change, there is no significant abnormal stock price reaction. This finding is in line with other studies on changes in governance (Warner et al. 1988; Wessels et al. 2017). Examination of the differences in stock price reactions regarding announcement of female and male CEO/CFO appointments shows that any differences between women and men are not statistically significant. This result contrasts with Lee and James (2007), who study 17 female top executive appointments in 1999-2000. We conclude that 
there is no significant difference in average abnormal returns after announcement of the appointment of a female $\mathrm{CEO} / \mathrm{CFO}$ versus a male $\mathrm{CEO} / \mathrm{CFO}$ appointment. This conclusion suggests that there is no gender difference regarding how investors value appointment of CEOs/CFOs.

The finding that gender of these top executives does not seem to be value relevant from the investor perspective contrasts with studies that employ alternative research designs that disregard the investor perspective or that focus on the board rather than CEOs/CFOs. Most studies find that firms with female directors generally somewhat underperform those consisting of only men (Ahern and Dittmar 2012; Chapple and Humphrey 2014 Lee and James 2007). It might be that strict reliance on market efficiency theory and the much larger sample are responsible for our result. Another difference is that our study is based on an international sample, whereas most previous studies focus on the US only. Further, our sample relates to a more recent period (when Sarbanes-Oxley regulation is in place) in which market participants have become more experienced with female CEOs/CFOs. The absence of a significant difference in the response to announcement of male and female CEO/CFO appointment also is in line with the prediction made by Lee and James (2007). These authors expected that, as women executives become less unique, there will be less difference in outcome variables between the announcement of male and female appointments. Finally, although our research design relies on efficient market theory, which has often been criticized as highly biased toward the status quo (Roscoe 2014; Sedláček 2011), it yields results that are in line with those based on other perspectives, such as agency theory (see Carter et al. 2003, 2010). Also, our method is much less plagued by endogeneity than most of the studies reviewed in Post and Byron (2015).

This study cannot be used to make inferences about the causality of news of appointment of top executives and the response (or the lack thereof) from stock market participants. However, several sensitivity checks were performed. These confirm the main findings; nevertheless, it is not possible to be entirely sure (type 1 and type 2 error may be present). Another important caveat to our conclusions is that although the study includes many more female top executives than most previous studies in this area, it faces data limitations. With 100 announcements of female CEO or CFO appointments, the sample is still quite small. Therefore, one cannot be sure that there is no gender effect of CEO/CFO 
appointments on shareholder value. It might be that investors do not perceive a value difference or there simply are not enough observations to filter out noise and allow statistical inference to convey the truth. In particular, expanding the analysis to a regression setting and accounting for controlling factors would require many more observations to warrant drawing robust conclusions. Further, our methodology can be applied only to public companies. In addition, our sample is skewed toward companies from industrialized countries. As such, we agree with Adams (2016) and Antonakis et al. (2010, 2014), who call for improved data and theory in this respect.

From a practical perspective, the implications of our study are that it seems that firms need not be afraid they will be punished by shareholders when they appoint women as CEOs or CFOs. However, our findings pertain only to the sample studied; they do not imply that appointment of women or men as such will never become value relevant. We trust that investors first and foremost will have a keen eye on the managerial qualities of the prospective CEO or CFO. 


\section{Appendices}

\section{Appendix A}

\section{$\underline{\text { Abbreviations }}$}

$\mathrm{N} \quad=$ number of firms

$\mathrm{L}_{\mathrm{i}} \quad=$ number of observed returns for security i $\left(\mathrm{M}_{\mathrm{i}}+\mathrm{W}_{\mathrm{i}}\right)$

$\mathrm{M}_{\mathrm{i}} \quad$ = number of non-missing estimation period returns for security $\mathrm{i}$

$\mathrm{W}_{\mathrm{i}} \quad=$ number of non-missing event window returns for security $\mathrm{i}$

$\mathrm{AR}_{\mathrm{i} . \mathrm{E}}=$ abnormal return of security $\mathrm{i}$ on the event day

$\mathrm{AR}_{\mathrm{i} . \tau}=$ abnormal return of security $\mathrm{i}$ on day $\tau$

$\mathrm{SR}_{\mathrm{i} . \mathrm{E}}=$ security i's standardized residual on the event day

$\mathrm{T}_{\tau} \quad=$ number of days in the estimation period

$\widehat{\mathrm{S}}_{\mathrm{I}} \quad=$ security i's estimated standard deviation abnormal returns in the estimation period

$\mathrm{R}_{\mathrm{m} . \mathrm{E}} \quad=$ market return on the event day

$\mathrm{R}_{\mathrm{m} . \tau} \quad=$ market return on day $\tau$

$\overline{\mathrm{R}}_{\mathrm{m}} \quad$ = average market return during the estimation period

$\mathrm{CAR}_{\mathrm{i}} \quad=$ cumulative abnormal return for security $\mathrm{i}$

$\tau_{1} . \tau_{2}=$ beginning and ending day of the cumulative window

$\operatorname{SCAR}_{\mathrm{i} \cdot[\tau 1 . \tau 2]}=$ standardized cumulative abnormal return

$\mathrm{S}_{\mathrm{CARi} .[\tau 1 . \tau 2]}=$ estimated standard deviation of each $\mathrm{CAR}_{\mathrm{i} .[\tau 1 . \tau 2]}$

$\overline{\mathrm{R}}_{\mathrm{m} \_ \text {est }}=$ mean daily national market-index return in the estimation period

$\mathrm{K}_{\mathrm{i} . \tau} \quad=$ rank of security $\mathrm{i}$ on day $\tau$

$\overline{\mathrm{K}} \quad$ = expected rank

$\mathrm{S}(\mathrm{K}) \quad=$ standard deviation of the sample mean abnormal return ranks 
$\underline{\text { Standardized cross-sectional test }}$

Average Abnormal Return (AAR)

Test statistic:

$\mathrm{Z}_{\tau}=\frac{1}{\mathrm{~N}} \sum_{\mathrm{i}=1}^{\mathrm{N}} \mathrm{SR}_{\mathrm{i} . \mathrm{E}} / \sqrt{\frac{1}{\mathrm{~N}(\mathrm{~N}-1)} \sum_{\mathrm{i}=1}^{\mathrm{N}}\left(\mathrm{SRi} . \mathrm{E}-\sum_{\mathrm{i}=1}^{\mathrm{N}} \frac{\mathrm{SRi.E}}{\mathrm{N}}\right)^{2}}$

with:

$\mathrm{SR}_{\mathrm{i} . \mathrm{E}}=\mathrm{AR}_{\mathrm{i} . \mathrm{E}} / \widehat{\mathrm{S}}_{\mathrm{i}} \sqrt{1+\frac{1}{\mathrm{~T} \tau}+\frac{(\mathrm{Rm} \cdot \mathrm{E}-\overline{\mathrm{R}} \mathrm{m})^{2}}{\sum_{\mathrm{t}=1}^{\mathrm{T \tau}}(\mathrm{Rm} \cdot \mathrm{t}-\overline{\mathrm{R}} \mathrm{m})^{2}}}$

Cumulative Average Abnormal Return (CAAR)

Standardized cumulative abnormal return:

$\operatorname{SCAR}_{\mathrm{i} .[\tau 1 . \tau 2]}=\mathrm{CAR}_{\mathrm{i} .[\tau 1 . \tau 2]} / \mathrm{S}_{\mathrm{CARi}[[1 . \tau 2]}$

with:

$\mathrm{S}_{\mathrm{CARi} .[\tau 1 . \tau 2]}=\left(\frac{1}{\mathrm{Mi}-2} \sum_{\mathrm{k}=-160}^{-3} \mathrm{ARi}^{2}\right)^{1 / 2}\left\{\mathrm{~W}_{\mathrm{i}}\left[1+\frac{\mathrm{Wi}}{\mathrm{Mi}}+\frac{\left(\sum_{\mathrm{t}=\tau 1}^{\tau 2} \mathrm{Rm} \cdot \tau-\mathrm{Wi} \overline{\mathrm{R}} \mathrm{m}_{\_} \text {est }\right)^{2}}{\left.\sum_{\mathrm{t}=-160}^{-3} \mathrm{Rm} \cdot \tau-\overline{\mathrm{R}} \mathrm{m}_{-} \text {est }\right)^{2}}\right]\right\}^{1 / 2}$

Test statistic:

$\mathrm{Z}_{\tau}=\frac{\sum_{\mathrm{i}=1}^{\mathrm{N}} \operatorname{SCARi}[\tau 1 . \tau 2]}{\sqrt{\mathrm{N} S S C A R}}$

where

$\mathrm{S}_{\mathrm{SCAR}}=\left[\frac{1}{\mathrm{~N}-1} \sum_{\mathrm{i}=1}^{\mathrm{N}}\left(\operatorname{SCARi}[\tau 1 . \tau 2]-\frac{1}{\mathrm{~N}} \sum_{\mathrm{i}=1}^{\mathrm{N}} \operatorname{SCARi}[\tau 1 . \tau 2]\right)^{2}\right]^{1 / 2}$ 


\section{$\underline{\text { Corrado's rank test }}$}

$\mathrm{K}_{\mathrm{i} . \tau}=\operatorname{rank}\left(\mathrm{AR}_{\mathrm{i} . \tau}\right)$

Test statistic:

$\mathrm{t}_{\text {rank }}=\frac{1}{\mathrm{~N}} \sum_{\mathrm{i}=1}^{\mathrm{N}}\left(\mathrm{K}_{\mathrm{i} . \tau}-\overline{\mathrm{K}}\right) / \mathrm{S}(\mathrm{K})$

where

$\mathrm{S}(\mathrm{K})=\left\{\frac{1}{\mathrm{Li}} \sum_{\mathrm{t}=-160}^{+2}\left[\left(\frac{1}{\mathrm{~N}} \sum_{\mathrm{i}=1}^{\mathrm{N}} \mathrm{Ki} . \tau\right)-\overline{\mathrm{K}}\right)^{2}\right\}^{1 / 2}$ 
Appendix B - Events and Matches (This appendix gives the key characteristics of all the events used in the analysis)

\begin{tabular}{|c|c|c|c|c|c|c|c|c|}
\hline \# & Company & Industry & CEO/CFO Full name & Gender & $\begin{array}{l}\text { Announce- } \\
\text { ment date }\end{array}$ & Position & $\begin{array}{r}\text { Total assets } \\
\text { (last available } \\
\text { year) } \\
1000 \text { USD } \\
\end{array}$ & $\begin{array}{l}\text { Country where } \\
\text { company is } \\
\text { headquartered }\end{array}$ \\
\hline 1 & RHI & $\begin{array}{l}\text { Chemicals, rubber, plastics, non-metallic } \\
\text { products }\end{array}$ & $\begin{array}{l}\text { Mag. Barbara Potisk- } \\
\text { Eibensteiner }\end{array}$ & $\mathrm{F}$ & $27-3-2012$ & CFO & 2.441 .286 & Austria \\
\hline M1 & $\begin{array}{l}\text { JAMES HARDIE } \\
\text { INDUSTRIES }\end{array}$ & $\begin{array}{l}\text { Chemicals, rubber, plastics, non-metallic } \\
\text { products }\end{array}$ & Mr Matthew Marsh & M & $12-6-2013$ & CFO & 2.107 .600 & Ireland \\
\hline 2 & BELGACOM & Post \& telecommunications & $\begin{array}{l}\text { Mrs Dominique Charlotte } \\
\text { Germaine Suzanne Leroy }\end{array}$ & $\mathrm{F}$ & 9-1-2014 & CEO & 10.833 .593 & Belgium \\
\hline M2 & $\begin{array}{l}\text { HELLENIC } \\
\text { TELECOMMUNICATIONS } \\
\text { ORGANIZATION }\end{array}$ & Post \& telecommunications & Mr Michael Tsamaz & M & $22-10-2010$ & CEO & 11.029 .920 & Greece \\
\hline 3 & GREENYARD FOODS & Food, beverages, tobacco & Mrs Valerie Vanhoutte & $\mathrm{F}$ & $23-10-2013$ & CFO & 1.003 .897 & Belgium \\
\hline M3 & $\begin{array}{l}\text { SENECA FOODS } \\
\text { TELENET GROUP }\end{array}$ & Food, beverages, tobacco & Mr Timothy Benjamin & M & $31-5-2012$ & CFO & 803.149 & USA \\
\hline 4 & HOLDING & Post \& telecommunications & Mrs Birgit Maria Conix & $\mathrm{F}$ & $26-8-2013$ & CFO & 5.411 .039 & Belgium \\
\hline M4 & HAVAS & Post \& telecommunications & Mr Francois Laroze & M & $16-12-2013$ & CFO & 6.222 .290 & France \\
\hline 5 & $\begin{array}{l}\text { GREENYARD FOODS } \\
\text { PHARMERICA }\end{array}$ & Food, beverages, tobacco & Mrs Marleen Vaesen & $\mathrm{F}$ & $9-10-2012$ & CEO & 1.003 .897 & Belgium \\
\hline M5 & CORPORATION & Wholesale \& retail trade & Mr David W. Froesel & M & 2-8-2013 & CEO & 886.300 & USA \\
\hline 6 & BRODRENE HARTMANN & Wholesale \& retail trade & Mrs Marianne Rorslev Bock & $\mathrm{F}$ & $27-2-2012$ & CFO & 201.693 & Denmark \\
\hline M6 & PANOSTAJA & Wholesale \& retail trade & Mr Simo Mustila & $M$ & $29-10-2010$ & CFO & 172.288 & Finland \\
\hline 7 & $\begin{array}{l}\text { TDC } \\
\text { HELLENIC } \\
\text { TELECOMMUNICATIONS }\end{array}$ & Post \& telecommunications & $\begin{array}{l}\text { Mrs Pernille Lyngvold } \\
\text { Erenbjerg }\end{array}$ & $\mathrm{F}$ & 21-3-2011 & CFO & 11.223.692 & Denmark \\
\hline M7 & ORGANIZATION & Post \& telecommunications & Mr Babis Mazarakis & M & $28-6-2012$ & CFO & 11.029 .920 & Greece \\
\hline
\end{tabular}




\begin{tabular}{|c|c|c|}
\hline 8 & SUOMINEN & Textiles, wearing apparel, leather \\
\hline M8 & IC COMPANYS & Textiles, wearing apparel, leather \\
\hline 9 & BOURSORAMA & Banks \\
\hline M9 & $\begin{array}{l}\text { AFFILIATED MANAGERS } \\
\text { GROUP }\end{array}$ & Banks \\
\hline 10 & $\begin{array}{l}\text { PIERRE ET VACANCES } \\
\text { PINNACLE }\end{array}$ & Hotels \& restaurants \\
\hline M10 & ENTERTAINMENT & Hotels \& restaurants \\
\hline 11 & ACCOR & Hotels \& restaurants \\
\hline M11 & $\begin{array}{l}\text { WYNDHAM } \\
\text { WORLDWIDE }\end{array}$ & Hotels \& restaurants \\
\hline 12 & JCDECAUX & Other services \\
\hline M12 & BUREAU VERITAS & Other services \\
\hline 13 & QSC & Post \& telecommunications \\
\hline M13 & BALDA & Post \& telecommunications \\
\hline & PFEIFFER VACUUM & \\
\hline 14 & TECHNOLOGY & Machinery, equipment, furniture, recycling \\
\hline M14 & PKC GROUP & Machinery, equipment, furniture, recycling \\
\hline 15 & $\begin{array}{l}\text { SMA SOLAR } \\
\text { TECHNOLOGY }\end{array}$ & Machinery, equipment, furniture, recycling \\
\hline M15 & ELRINGKLINGER & Machinery, equipment, furniture, recycling \\
\hline 16 & DEUTSCHE LUFTHANSA & Transport \\
\hline M16 & $\begin{array}{l}\text { UNITED CONTINENTAL } \\
\text { HOLDINGS }\end{array}$ & Transport \\
\hline 17 & NORDWEST HANDEL & Wholesale \& retail trade \\
\hline M17 & SHW & Wholesale \& retail trade \\
\hline 18 & CELESIO & Wholesale \& retail trade \\
\hline M18 & WOLSELEY & Wholesale \& retail trade \\
\hline
\end{tabular}

\begin{tabular}{|c|c|c|c|c|c|}
\hline Mrs Nina Marietta Kopola & $\mathrm{F}$ & 22-11-2011 & CEO & 368.033 & Finland \\
\hline Mr Rud Trabjerg Pedersen & $\mathrm{M}$ & $21-8-2013$ & CEO & 353.067 & Denmark \\
\hline Mrs Marie Cheval & $\mathrm{F}$ & $19-3-2013$ & CEO & 6.384 .972 & France \\
\hline Mr Sean M. Healey & M & $26-10-2010$ & CEO & 6.187 .100 & USA \\
\hline $\begin{array}{l}\text { Mrs Francoise Dominique } \\
\text { Raymonde Gri }\end{array}$ & $\mathrm{F}$ & $5-11-2012$ & CEO & 2.214 .300 & France \\
\hline Mr Anthony Sanfilippo & M & $15-3-2010$ & CEO & 2.108 .994 & USA \\
\hline Mrs Sophie Stabile & $\mathrm{F}$ & $10-5-2010$ & CFO & 9.974 .664 & France \\
\hline Mr Thomas G. Conforti & M & 8-9-2009 & CFO & 9.463 .000 & USA \\
\hline Mrs Laurence Debroux & $\mathrm{F}$ & $6-5-2010$ & CFO & 5.734 .772 & France \\
\hline Mr Sami Badarani & M & 2-11-2011 & CFO & 5.020 .317 & France \\
\hline Mrs Barbara Stolz & $\mathrm{F}$ & 20-3-2013 & CFO & 510.777 & Germany \\
\hline Mr Dieter Brenken & M & $5-9-2013$ & CFO & 470.447 & Germany \\
\hline Mrs Nathalie Benedikt & $\mathrm{F}$ & 6-11-2012 & CFO & 588.006 & Germany \\
\hline Mr Juha Torniainen & M & $4-4-2012$ & CFO & 639.987 & Finland \\
\hline Mrs Lydia Rosina Sommer & $\mathrm{F}$ & $17-10-2012$ & CFO & 1.753 .055 & Germany \\
\hline Mr Stefan Wolf & M & $28-1-2005$ & CFO & 1.673 .779 & Germany \\
\hline Miss Simone Menne & $\mathrm{F}$ & $7-5-2012$ & CFO & 37.496 .027 & Germany \\
\hline Mr John Rainey & M & $16-4-2012$ & CFO & 37.628 .000 & USA \\
\hline Mrs Annegret Franzen & $\mathrm{F}$ & $14-2-2012$ & CFO & 224.648 & Germany \\
\hline Mr Sascha Rosengart & M & $7-5-2013$ & CFO & 237.458 & Germany \\
\hline Mrs Marion Helmes & $\mathrm{F}$ & $20-12-2011$ & CFO & 10.461 .126 & Germany \\
\hline Mr John Martin & M & 25-1-2010 & CFO & 10.783 .414 & $\underline{\text { UK }}$ \\
\hline
\end{tabular}




\begin{tabular}{|c|c|c|c|c|c|c|c|c|}
\hline 19 & ALNO AG & Machinery, equipment, furniture, recycling & Mrs Ipek Demirtas & $\mathrm{F}$ & $13-7-2011$ & CFO & 221.992 & Germany \\
\hline M19 & SUSS MICROTEC & Machinery, equipment, furniture, recycling & Mr Michael Knpp & M & $10-5-2007$ & CFO & 237.605 & Germany \\
\hline & NATIONAL BANK OF & & & & & & & \\
\hline 20 & GREECE SA & Banks & Miss Paula N. Hadjisotiriou & $\mathrm{F}$ & $10-7-2013$ & CFO & 138.271 .532 & Greece \\
\hline M20 & $\begin{array}{l}\text { ANNALY CAPITAL } \\
\text { MANAGEMENT }\end{array}$ & Banks & Mr Glenn A. Votek & $M$ & $19-8-2013$ & CFO & 133.452 .300 & USA \\
\hline 21 & INGERSOLL-RAND & Machinery, equipment, furniture, recycling & Mrs Susan K Carter & $\mathrm{F}$ & $5-9-2013$ & CFO & 18.492 .900 & Ireland \\
\hline M21 & PACCAR & Machinery, equipment, furniture, recycling & Mr Robert Christensen & M & $30-12-2012$ & CFO & 18.627 .800 & USA \\
\hline 22 & $\begin{array}{l}\text { GLOBAL INDEMNITY PLC } \\
\text { TRIPLE-S }\end{array}$ & Insurance companies & Mrs Cynthia Y Valko & $\mathrm{F}$ & $15-9-2011$ & CEO & 1.903 .703 & Ireland \\
\hline M22 & $\begin{array}{l}\text { MANAGEMENT } \\
\text { GRUPPO EDITORIALE }\end{array}$ & Insurance companies & Mr Mr. Amilcar L. Jordan & M & $5-6-2012$ & CEO & 2.059 .344 & USA \\
\hline 23 & L'ESPRESSO & Publishing, printing & Mrs Monica Mondardini & $\mathrm{F}$ & $29-4-2013$ & CEO & 1.732 .933 & Italy \\
\hline M23 & PTC. & Publishing, printing & Mr James E Heppelman & M & $10-5-2010$ & CEO & 1.828 .906 & USA \\
\hline \multirow[t]{2}{*}{24} & IL SOLE 24 ORE & Publishing, printing & Mrs Donatella Treu & $\mathrm{F}$ & $12-3-2010$ & CEO & 669.362 & Italy \\
\hline & $\begin{array}{l}\text { INDEPENDENT NEWS \& } \\
\text { MEDIA PUBLIC LIMITED }\end{array}$ & & & & & & & \\
\hline M24 & COMPANY & Publishing, printing & Mr Vincent Crowley & M & $19-4-2012$ & CEO & 593.730 & Ireland \\
\hline 25 & HURTIGRUTEN & Transport & Mrs Asta Sofie Lassesen & $\mathrm{F}$ & $6-9-2011$ & CFO & 946.174 & Norway \\
\hline M25 & ARKANSAS BEST & Transport & Mr Michael Newcity & M & $28-5-2010$ & CFO & 1.034 .462 & USA \\
\hline 26 & RTL GROUP & Other services & Mrs Anke Schaeferkordt & $\mathrm{F}$ & $7-2-2012$ & CEO & 10.420 .621 & Luxembourg \\
\hline M26 & GAGFAH & Other services & Mr Thomas Zinnocker & $M$ & $22-3-2013$ & CEO & 10.702 .049 & Luxembourg \\
\hline 27 & ORDINA N & Post \& telecommunications & $\begin{array}{l}\text { Mrs Marijke Jolanda Poots } \\
\text { Bijl }\end{array}$ & $\mathrm{F}$ & $28-3-2013$ & CFO & 418.231 & Netherlands \\
\hline M27 & IDT CORP & Post \& telecommunications & Mr Marcelo Fisscher & M & $6-6-2006$ & CFO & 435.407 & USA \\
\hline & SENSATA & & Ms Martha Newman & & & & & \\
\hline 28 & TECHNOLOGIES & Machinery, equipment, furniture, recycling & Sullivan & $\mathrm{F}$ & $25-4-2012$ & CEO & 3.648 .391 & Netherlands \\
\hline M28 & TRELLEBORG & Machinery, equipment, furniture, recycling & Mr Peter Nilsson & M & $9-6-2005$ & CEO & 4.174 .033 & Sweden \\
\hline
\end{tabular}




$\begin{array}{rll}29 & \text { POSTNL } & \text { Post \& telecommunications } \\ \text { M29 } & \text { HAVAS } & \text { Post \& telecommunications } \\ 30 & \text { HAFSLUND } & \text { Gas, Water, Electricity } \\ \text { M30 } & \text { DYNEGY } & \text { Gas, Water, Electricity } \\ & \text { GJENSIDIGE } & \\ 31 & \text { FORSIKRING } & \text { Insurance companies }\end{array}$

M31 CINCINNATI FINANCIAL Insurance companies

\begin{tabular}{|c|c|c|}
\hline 32 & SWEDISH MATCH & Food, beverages, tobacco \\
\hline M32 & HAIN CELESTIAL GROUP & Food, beverages, tobacco \\
\hline 33 & KNOWIT & Other services \\
\hline M33 & PROACT IT GROUP & Other services \\
\hline 34 & ELECTRA GRUPPEN & Machinery, equipment, furniture, recycling \\
\hline M34 & VITROLIFE & Machinery, equipment, furniture, recycling \\
\hline 35 & HEXPOL & $\begin{array}{l}\text { Chemicals, rubber, plastics, non-metallic } \\
\text { products }\end{array}$ \\
\hline M35 & $\begin{array}{l}\text { STO } \\
\text { AKTIENGESELLSCHAFT }\end{array}$ & $\begin{array}{l}\text { Chemicals, rubber, plastics, non-metallic } \\
\text { products }\end{array}$ \\
\hline 36 & CYBERCOM GROUP & Other services \\
\hline M36 & TRADEDOUBLER & Other services \\
\hline 37 & RATOS & Other services \\
\hline M37 & FUGRO & Other services \\
\hline 38 & REJLERS & Other services \\
\hline & VICTORIA PARK A & Other services \\
\hline
\end{tabular}

Mrs Hendrica Verhagen
Mr Yannick Bolloré
Mrs Heidi Ulmo
Mr Clint C. Freeland
Mrs Catharina Elisabeth
Hellerud
Mr Michael J. Sewell
Mrs Marlene Forsell
Mr Stephen J. Smith
Mrs Anna Jennehov
Mr Kristian Shaw
Mrs Anneli Sjostedt
Mr Thomas Axelsson
Mrs Karin Elisabeth
Bachmann Gunnarsson
Mr Rolf Wohrle
Mrs Camilla Oberg
Mr Rob Wilson
Mrs Susanna Margareta
Campbell
Mr P. van Riel
Mrs Eva Katarina Viola
Nygren
Mr Peter Strand

F

M

F

M

F

M

F

M

$\mathrm{F}$

M

$\mathrm{F}$

M

F
19-4-2012 CEO

8-1-2014 CEO

30-4-2012 CFO

23-6-2011 CFO

16-12-2011 CFO

25-4-2011 CFO

9-9-2013 CFO

21-8-2013 CFO

5-12-2012 CFO

13-11-2013 CFO

5-9-2012 CEO

18-4-2012 CEO

17-8-2012 CFO

31-8-2010 CFO

10-4-2012 CFO

29-6-2012 CFO

26-1-2012 CEO

16-1-2006 CEO

12-1-2012 CEO

21-8-2013 CEO
6.143.126 Netherlands

6.222.290 France

4.451.346 Norway

4.535 .000 USA

16.792.406 Norway

16.192.000 USA

2.209.394 Sweden

2.258.494 USA

248.125 Sweden

229.504 Sweden

72.048 Sweden

71.058 Sweden

908.141 Sweden

902.798 Germany

208.189 Sweden

182.962 Sweden

5.161.042 Sweden

5.501.523 Netherlands

107.925 Sweden

107.251 Sweden 
39 ASSA ABLOY

M39 SSAB

40 ACANDO

MARTHA STEWART

M40 LIVING OMNIMEDIA

41 BEIJER ELECTRONICS

M41 LAGERCRANTZ GROUP

42 BILLERUDKORSNAS AB

M42 METSA BOARD

\section{INVESTOR AUTOMATIC DATA}

M43 PROCESSING

44 ATRIUM LUUNGBERG MOODY'S

M44 CORPORATION

45 ADDTECH

M45 CDI

DECHRA

46 PHARMACEUTICALS

M46 MCBRIDE

47 IMPELLAM GROUP

MICHAEL PAGE

M47 INTERNATIONAL

48 SMITH \& NEPHEW

M48 MEGGITT
Metals \& metal products

Metals \& metal products

Publishing, printing

Publishing, printing

Machinery, equipment, furniture, recycling

Machinery, equipment, furniture, recycling

Wood, cork, paper

Wood, cork, paper

Other services

Other services

Other services

Other services

Other services

Other services

Chemicals, rubber, plastics, non-metallic products

Chemicals, rubber, plastics, non-metallic products

Other services

Other services

Machinery, equipment, furniture, recycling Machinery, equipment, furniture, recycling
Mrs Carolina Dybeck

Happe

$\mathrm{F}$

Mr Hakan Folin

12-12-2011 CFO

9.202.245 Sweden

Mrs Anneli Elisabeth

Lindblom

Mr Ken West

M

Mrs Anna Kristina Belfrage $\quad F$

Mr Bengt Lejdström

Miss Susanne Karin

Lithander

Mr Markus Holm

Ms Susanne Maria

Elisabeth Ekblom

Mr Jan Siegmund

Ingalill Berglund

27-2-2013 CFO

9-11-2011 CFO

6-9-2011 CFO

29-8-2011 CFO

28-9-2011 CFO

11-7-2011 CFO

13-9-2013 CFO

29-4-2011 CFO

1-11-2012 CFO

14-3-2011 CEO

26-4-2005 CEO

Mr Raymond W. McDaniel M

Mrs Kristina Willgard

9-7-2010 CFO

25-8-2011 CFO

31-1-2013 CFO

3-8-2009 CFO

8-4-2013 CEO

16-12-2005 CEO

19-11-2012 CFO

6-6-2013 CFO
9.012.069 Sweden

162.432 Sweden

154.260 USA

217.856 Sweden

245.670 Sweden

3.800.907 Sweden

3.403.392 Finland

35.305.558 Sweden

32.268.100 USA

3.915.274 Sweden

3.960 .900 USA

469.272 Sweden

400.705 USA

637.551 UK

692.185 UK

590.961 UK

545.606 UK

5.642.000 UK

6.130 .056 UK 


\begin{tabular}{|c|c|c|}
\hline 49 & RECKITT BENCKISER & $\begin{array}{l}\text { Chemicals, rubber, plastics, non-metallic } \\
\text { products }\end{array}$ \\
\hline M49 & MONSANTO & $\begin{array}{l}\text { Chemicals, rubber, plastics, non-metallic } \\
\text { products }\end{array}$ \\
\hline 50 & DIAGEO & Food, beverages, tobacco \\
\hline & BRITISH AMERICAN & \\
\hline M50 & TOBACCO & Food, beverages, tobacco \\
\hline 51 & EASYJET & Transport \\
\hline M51 & IRON MOUNTAIN & Transport \\
\hline 52 & LACLEDE GROUP & Gas, Water, Electricity \\
\hline M52 & $\begin{array}{l}\text { DAYTON POWER AND } \\
\text { LIGHT COMPANY }\end{array}$ & Gas, Water, Electricity \\
\hline 53 & $\begin{array}{l}\text { AMBAC FINANCIAL } \\
\text { GROUP }\end{array}$ & Insurance companies \\
\hline M53 & SPARK NETWORKS & Other services \\
\hline 54 & $\begin{array}{l}\text { HEWLETT-PACKARD } \\
\text { COMPAN }\end{array}$ & Machinery, equipment, furniture, recycling \\
\hline M54 & INTEL & Machinery, equipment, furniture, recycling \\
\hline 55 & JPMORGAN CHASE \& & Banks \\
\hline M55 & BANK OF AMERICA & Banks \\
\hline 56 & $\begin{array}{l}\text { EXPRESS SCRIPTS } \\
\text { HOLDING }\end{array}$ & Wholesale \& retail trade \\
\hline M56 & CARREFOUR & Wholesale \& retail trade \\
\hline 57 & MICROSOFT & Publishing, printing \\
\hline & INTERNATIONAL & \\
\hline M57 & BUSINESS MACHINES & Other services \\
\hline
\end{tabular}

Ms Mary Elizabeth Doherty
Mr Pierre Courduroux
Mrs Deirdre Ann Mahlan
Mr Ben Stevens
Ms Carolyn Julia McCall
Mr William Meaney
Mrs Suzanne Sitherwood
Mr Phil Herrington
Mrs Diana Newman Adams
Mr Greg Liberman
Mrs Meg Whitman
Mr Brian Krzanich
Miss Marianne Lake
Mr Bruce Thompson
Mrs Catherine R Smith
Mr Pierre-Jean Sivignon
Mrs Amy E Hood

Mr Martin J. Schroeter
23-11-2010 CFO

22-12-2010 CFO

11-5-2010 CFO

28-2-2008 CFO

23-3-2010 CEO

3-12-2012 CEO

21-6-2011 CEO

5-3-2012 CEO

13-6-2011 CEO

11-4-2011 CEO

22-9-2011 CEO

2-5-2013 CEO

19-11-2012 CFO

15-4-2011 CFO

14-1-2014 CFO

26-9-2013 CFO

8-5-2013 CFO

7-11-2013 CFO
23.796.239 UK

20.664.000 USA

38.513.256 UK

43.122.005 UK

7.126.704 UK

6.358.339 USA

3.125.386 USA

3.464 .200 USA

26.165 USA

28.364 USA

105.676.000 USA

92.358 .000 USA

2.415.689.000 USA

2.102.273.000 USA

58.111.200 USA

60.486.571 France

142.431 .000 USA

126.223 .000 USA 


\begin{tabular}{|c|c|c|c|c|c|c|c|c|}
\hline \multirow[t]{2}{*}{58} & BEST BUY CO & Wholesale \& retail trade & Mrs Sharon L McCollam & $\mathrm{F}$ & $12-11-2012$ & CFO & 16.787 .000 & USA \\
\hline & \multicolumn{8}{|l|}{ LIBERTY INTERACTIVE } \\
\hline M58 & INTERACTIVE GROUP & Wholesale \& retail trade & Mr Christopher W. Shean & M & $25-10-2011$ & CFO & 15.115 .000 & USA \\
\hline \multirow[t]{2}{*}{59} & INTERNATIONAL PAPER & Wood, cork, paper & Mrs Carol Louise Roberts & $\mathrm{F}$ & $25-10-2011$ & CFO & 31.528 .000 & USA \\
\hline & \multicolumn{8}{|l|}{ NATIONAL OILWELL } \\
\hline M59 & VARCO. & Wholesale \& retail trade & Mr Jeremy Thigpen & $\mathrm{M}$ & $6-12-2012$ & CFO & 31.484 .000 & USA \\
\hline 60 & STAPLES & Wholesale \& retail trade & Mrs Christine T Komola & $\mathrm{F}$ & $27-9-2011$ & CFO & 12.280 .005 & USA \\
\hline M60 & SYSCO & Wholesale \& retail trade & Mr R. Chris Kreidler & M & $10-9-2009$ & CFO & 12.663 .947 & USA \\
\hline 61 & $\begin{array}{l}\text { OCCIDENTAL } \\
\text { PETROLEUM }\end{array}$ & Primary sector & Mrs Cynthia L Walker & $\mathrm{F}$ & $20-7-2012$ & CFO & 64.210 .000 & USA \\
\hline M61 & APACHE & Primary sector & Mr Alfonso Leon & M & $14-2-2014$ & CFO & 60.737 .000 & USA \\
\hline \multirow[t]{2}{*}{62} & XEROX & Other services & Mrs Kathryn A Mikells & $\mathrm{F}$ & $28-3-2013$ & CFO & 30.015 .000 & USA \\
\hline & \multicolumn{8}{|l|}{ CAESARS } \\
\hline M62 & CORPORATION & Other services & Mr Donald Colvin & M & $15-11-2012$ & CFO & 27.998 .100 & USA \\
\hline \multirow[t]{2}{*}{63} & SOUTHWEST AIRLINES & Transport & Ms Tammy Romo & $\mathrm{F}$ & $30-8-2012$ & CFO & 19.345 .000 & USA \\
\hline & \multicolumn{8}{|l|}{ PLAINS ALL AMERICAN } \\
\hline M63 & PIPELINE & Transport & Mr Al Swanson & M & 21-8-2007 & CFO & 19.235 .000 & USA \\
\hline 64 & GLOBAL PARTNERS & Wholesale \& retail trade & Mrs Daphne H Foster & $\mathrm{F}$ & $24-4-2013$ & CFO & 2.329 .752 & USA \\
\hline M64 & NGL ENERGY PARTNERS & Wholesale \& retail trade & Mr Atanas H. Atanasov & M & $8-5-2013$ & CFO & 2.291 .347 & USA \\
\hline 65 & NORFOLK SOUTHERN & Transport & Ms Marta R Stewart & $\mathrm{F}$ & $20-9-2013$ & CFO & 30.342 .000 & USA \\
\hline M65 & CSX CORP & Transport & Mr Fredrik J. Eliassion & $M$ & 23-1-2012 & CFO & 31.782 .000 & USA \\
\hline 66 & AVON PRODUCTS & $\begin{array}{l}\text { Chemicals, rubber, plastics, non-metallic } \\
\text { products }\end{array}$ & $\begin{array}{l}\text { Mrs Sherilyn S. (Sheri) } \\
\text { McCoy }\end{array}$ & $\mathrm{F}$ & $9-4-2012$ & CEO & 7.382 .500 & USA \\
\hline M66 & $\begin{array}{l}\text { ENDO HEALTH } \\
\text { SOLUTIONS. }\end{array}$ & $\begin{array}{l}\text { Chemicals, rubber, plastics, non-metallic } \\
\text { products }\end{array}$ & Mr Rajiv De Silva & $\mathrm{M}$ & $25-2-2013$ & CEO & 6.568 .559 & USA \\
\hline
\end{tabular}




\begin{tabular}{|c|c|c|c|c|c|c|c|c|}
\hline 67 & AVON PRODUCTS & $\begin{array}{l}\text { Chemicals, rubber, plastics, non-metallic } \\
\text { products }\end{array}$ & Mrs Kimberly A Ross & $\mathrm{F}$ & $23-5-2011$ & CFO & 7.382 .500 & USA \\
\hline & ENDO HEALTH & Chemicals, rubber, plastics, non-metallic & & & & & 6.568 .559 & \\
\hline M67 & SOLUTIONS & products & Mr Suketu Upadhyay & M & $9-9-2013$ & CFO & & USA \\
\hline 68 & FAMILY DOLLAR STORES & Wholesale \& retail trade & Mrs Mary A Winston & $\mathrm{F}$ & $10-4-2012$ & CFO & 3.709 .861 & USA \\
\hline M68 & $\begin{array}{l}\text { IAC/INTERACTIVE } \\
\text { GROUP }\end{array}$ & Wholesale \& retail trade & Mr Jeff Kip & M & $6-2-2012$ & CFO & 3.805 .828 & USA \\
\hline 69 & $\begin{array}{l}\text { ESTEE LAUDER } \\
\text { COMPANIES }\end{array}$ & $\begin{array}{l}\text { Chemicals, rubber, plastics, non-metallic } \\
\text { products } \\
\text { Chemicals, rubber, plastics, non-metallic }\end{array}$ & Miss Tracey Thomas Travis & $\mathrm{F}$ & 19-7-2012 & CFO & 7.145 .200 & USA \\
\hline M69 & OWENS CORNING & products & Mr Michael C. Mcmurray & M & $16-8-2012$ & CFO & 7.568 .000 & USA \\
\hline 70 & XCEL ENERGY & Gas, Water, Electricity & Mrs Teresa S Madden & $\mathrm{F}$ & $19-9-2011$ & CFO & 31.140 .686 & USA \\
\hline M70 & NRG ENERGY & Gas, Water, Electricity & Mr Kirkland Andrews & M & $17-8-2011$ & CFO & 35.128 .000 & USA \\
\hline & PUBLIC SERVICE & & & & & & & \\
\hline 71 & ENTERPRISE GROUP & Gas, Water, Electricity & Mrs Caroline Dolores Dorsa & $\mathrm{F}$ & $17-3-2011$ & CFO & 31.725 .000 & USA \\
\hline M71 & $\begin{array}{l}\text { GEORGIA POWER } \\
\text { COMPANY }\end{array}$ & Gas, Water, Electricity & Mr W. Ron Hinson & M & 4-1-2013 & CFO & 28.803 .000 & USA \\
\hline 72 & HORMEL FOODS & Primary sector & Mrs Jody H Feragen & $\mathrm{F}$ & 29-9-2010 & CFO & 4.915 .880 & USA \\
\hline & TARGA RESOURCES & & & & & & & \\
\hline M72 & PARTNERS LP & Primary sector & Mr Matthew J. Meloy & M & $20-12-2010$ & CFO & 5.025 .700 & USA \\
\hline 73 & SEALED AIR & Wood, cork, paper & Mrs Carol P Lowe & $\mathrm{F}$ & $24-5-2012$ & CFO & 9.331 .700 & USA \\
\hline M73 & MEADWESTVACO & Wood, cork, paper & Mr E. Mark Rajkowski & M & 19-7-2004 & CFO & 10.283 .000 & USA \\
\hline & $\begin{array}{l}\text { COGNIZANT } \\
\text { TECHNOLOGY }\end{array}$ & & & & & & & \\
\hline 74 & SOLUTIONS & Other services & Mrs Karen McLoughlin & $\mathrm{F}$ & $8-2-2012$ & CFO & 6.521 .571 & USA \\
\hline M74 & ECHOSTAR & Other services & Mr David Rayner & M & $4-12-2012$ & CFO & 6.600 .233 & USA \\
\hline 75 & FMC TECHNOLOGIES & Machinery, equipment, furniture, recycling & Mrs Maryann T. Seaman & $\mathrm{F}$ & $4-11-2011$ & CFO & 5.902 .900 & USA \\
\hline M75 & FIRST SOLAR & Machinery, equipment, furniture, recycling & Mr Mark Widmar & M & $15-3-2011$ & CFO & 6.348 .692 & USA \\
\hline
\end{tabular}




\begin{abstract}
76 CELGENE CORP
\end{abstract}
Other services

M76 ADT CORPORATION

Other services

$77 \mathrm{COACH}$

M77 MRC GLOBAL

78 CVR ENERGY

M78 TIDEWATER

79 KRAFT FOODS GROUP

M79 CONAGRA FOODS RESOLUTE FOREST

80 PRODUCTS

M80 DS SMITH

81 NVIDIA

M81 TEREX COP

82 JONES LANG LASALLE

M82 H\&R BLOCK

AMERICAN EAGLE

83 OUTFITTERS

M83 BIG LOTS

84 CARLYLE GROUP L.P. GENERAL GROWHTH

M84 PROPERTIE AMERICAN WATER

85 WORKS COMPANY

M85 PEPCO HOLDINGS

86 COVANCE

M86 STARZ
Wholesale \& retail trade

Wholesale \& retail trade

Primary sector

Primary sector

Food, beverages, tobacco

Food, beverages, tobacco

Wood, cork, paper

Wood, cork, paper

Machinery, equipment, furniture, recycling

Machinery, equipment, furniture, recycling

\section{Other services}

Other services

Wholesale \& retail trade

Wholesale \& retail trade

Other services

Other services

Gas, Water, Electricity

Gas, Water, Electricity

Other services

Other services

\begin{tabular}{|c|c|}
\hline Mrs Jacqualyn A Fouse & 1 \\
\hline Mr Michael Geltzeiler & \\
\hline Mrs Jane H Nielsen & \\
\hline Mr James Braun & \\
\hline Mrs Susan M Ball & \\
\hline Mr Quinn P. Fanning & \\
\hline Mrs Teri L. List-Stoll & \\
\hline Mr John F. Gehring & \\
\hline Mrs Jo-Ann Longworth & \\
\hline Mr Adrian Marsh & \\
\hline Mrs Colette Kress & \\
\hline Mr Kevin Bradley & \\
\hline Mrs Christie B Kelly & \\
\hline Mr Gregory J. Macfarlane & \\
\hline Mrs Mary M Boland & \\
\hline Mr Timothy A. Johnson & \\
\hline Mrs Adena T Friedman & \\
\hline Mr Michael B. Berman & \\
\hline Mrs Susan N Story & \\
\hline Mr Frederick Boyle & \\
\hline Ms Alison Ann Cornell & \\
\hline Mr Scott Macdonald & \\
\hline
\end{tabular}

26-8-2010 CFO

11.734.306 USA

14-10-2013 CFO

9.913.000 USA

27-7-2011 CFO

17-10-2011 CFO

27-7-2012 CFO

31-7-2008 CFO

3-9-2013 CFO

16-1-2009 CFO

20-7-2011 CFO

20-6-2013 CFO

16-9-2013 CFO

14-1-2013 CFO

16-5-2013 CFO

23-5-2012 CFO

31-5-2012 CFO

23-8-2012 CFO

13-2-2011 CFO

28-11-2011 CFO

20-2-2013 CFO

26-3-2012 CFO

2-5-2012 CFO

9-7-2012 CFO
3.531 .897 USA

3.369 .727 USA

4.023 .400 USA

4.168 .055 USA

23.267.000 USA

6.333 .000 USA

5.597 .699 USA

6.412.245 USA

6.746 .200 USA

4.351.499 USA

4.537 .779 USA

1.756.053 USA

1.753 .626 USA

31.566 .600 USA

27.282.405 USA

14.718.976 USA

15.794 .000 USA

2.556 .588 USA

2.176 .050 USA
20.405.300 USA 


\begin{tabular}{|c|c|c|c|c|c|c|c|c|}
\hline 87 & CHICOS FAS & Wholesale $\&$ retail trade & Mrs Pamela K Knous & $\mathrm{F}$ & 23-6-2011 & CFO & 1.580 .628 & USA \\
\hline M87 & TITAN MACHINERY & Wholesale \& retail trade & Mr Mark Kalvoda & M & $11-4-2011$ & CFO & 1.444 .074 & USA \\
\hline \multirow[t]{2}{*}{88} & MARKEL CORPORATION & Insurance companies & Mrs Anne G Waleski & $\mathrm{F}$ & $10-5-2010$ & CFO & 11.777 .814 & USA \\
\hline & HANOVER INSURANCE & & & & & & & \\
\hline M88 & GROUP & Insurance companies & Mr David Greenfield & M & $15-12-2010$ & CFO & 11.410 .600 & USA \\
\hline \multirow[t]{2}{*}{89} & COMERICA & Banks & Mrs Karen L Parkhill & $\mathrm{F}$ & 27-7-2011 & CFO & 65.227 .000 & USA \\
\hline & DISCOVER FINANCIAL & & & & & & & \\
\hline M89 & SERVICES & Banks & Mr Mark Graf & M & 4-4-2011 & CFO & 73.491 .315 & USA \\
\hline 90 & $\mathrm{AOL}$ & Other services & Mrs Karen E Dykstra & $\mathrm{F}$ & $19-9-2012$ & CFO & 2.983 .400 & USA \\
\hline \multirow[t]{2}{*}{ M90 } & AKAMAI TECHNOLOGIES & Other services & Mr James Benson & M & $8-2-2012$ & CFO & 2.600 .627 & USA \\
\hline & VISHAY & & & & & & & \\
\hline 91 & INTERTECHNOLOGY IC & Machinery, equipment, furniture, recycling & Mrs Lori Lipcaman & $\mathrm{F}$ & $17-8-2011$ & CFO & 3.016 .277 & USA \\
\hline \multirow[t]{2}{*}{ M91 } & BABCOCK \& WILCOX & Machinery, equipment, furniture, recycling & Mr Anthony Colatrella & M & $14-11-2011$ & CFO & 2.840 .355 & USA \\
\hline & GRANITE & & & & & & & \\
\hline 92 & CONSTRUCTION & Construction & Mrs Laurel J Krzeminski & $\mathrm{F}$ & $9-11-2010$ & CFO & 1.729 .487 & USA \\
\hline M92 & M.D.C. HOLDINGS & Construction & Mr John M. Stephens & M & $30-1-2012$ & CFO & 1.945 .441 & USA \\
\hline 93 & TORO & Machinery, equipment, furniture, recycling & Mrs Renee J Peterson & $\mathrm{F}$ & 29-7-2011 & CFO & 1.002 .748 & USA \\
\hline M93 & IDEXX LABORATORIES & Machinery, equipment, furniture, recycling & Mr Brian McKeon & M & $15-10-2013$ & CFO & 1.103 .602 & USA \\
\hline \multirow[t]{2}{*}{94} & LOUISIANA PACIFIC & Wood, cork, paper & Ms Sallie B Bailey & $\mathrm{F}$ & $11-7-2011$ & CFO & 2.331 .000 & USA \\
\hline & MAYR-MELNHOF & & & & & & & \\
\hline M94 & KARTON & Wood, cork, paper & Mr Oliver Schumy & M & $7-5-2008$ & CFO & 2.147 .219 & USA \\
\hline 95 & MCCLATCHY & Publishing, printing & Mrs Elaine Lintecum & $\mathrm{F}$ & $16-5-2012$ & CFO & 3.005 .131 & USA \\
\hline \multirow[t]{2}{*}{ M95 } & JOHN WILEY \& SONS & Publishing, printing & Mr John Kritzmacher & M & $3-6-2013$ & CFO & 2.806 .375 & USA \\
\hline & MINE SAFETY & & & & & & & \\
\hline 96 & APPLIANCES & Machinery, equipment, furniture, recycling & Mrs Stacy McMahan & $\mathrm{F}$ & $5-9-2013$ & CFO & 1.111 .746 & USA \\
\hline M96 & KAMAN & Machinery, equipment, furniture, recycling & Mr Robert D. Starr & $M$ & $18-4-2013$ & CFO & 1.096 .993 & USA \\
\hline
\end{tabular}




\begin{tabular}{|c|c|c|c|c|c|c|c|c|}
\hline & CBL \& ASSOCIATES & & & & & & & \\
\hline 97 & PROPERTIES & Other services & Mrs Farzana K Mitchell & $\mathrm{F}$ & $10-9-2012$ & CFO & 7.089 .736 & USA \\
\hline M97 & EXPEDIA & Other services & Mr Mark Okerstrom & M & $1-9-2011$ & CFO & 7.085 .195 & USA \\
\hline 98 & SELECT COMFORT & Machinery, equipment, furniture, recycling & Ms Wendy Lee Schoppert & $\mathrm{F}$ & $9-5-2011$ & CFO & 342.021 & USA \\
\hline & SMITH \& WESSON & & & & & & & \\
\hline M98 & HOLDING & Wholesale \& retail trade & Mr Jeffrey D. Buchanan & M & 21-12-2010 & CFO & 326.989 & USA \\
\hline 99 & $\begin{array}{l}\text { TECUMSEH PRODUCTS } \\
\text { LINDSAY }\end{array}$ & Machinery, equipment, furniture, recycling & Mrs Janice E Stipp & $\mathrm{F}$ & $18-10-2011$ & CFO & 527.900 & USA \\
\hline M99 & CORPORATION & Machinery, equipment, furniture, recycling & Mr James Raabe & M & $9-5-2011$ & CFO & 512.296 & USA \\
\hline 100 & $\begin{array}{l}\text { NAVIGANT } \\
\text { CONSULTING } \\
\text { WINTHROP REALTY }\end{array}$ & Other services & Mrs Lucinda M Baier & $\mathrm{F}$ & $25-2-2013$ & CFO & 954.450 & USA \\
\hline M100 & TRUST & Other services & Mr John Garilli & M & $25-5-2012$ & CFO & 923.163 & USA \\
\hline 101 & WAUSAU PAPER. & Wood, cork, paper & Mrs Sherri L Lemmer & $\mathrm{F}$ & $30-4-2012$ & CFO & 700.715 & USA \\
\hline M101 & $\begin{array}{l}\text { POTLATCH } \\
\text { STRATEGIC HOTELS \& }\end{array}$ & Wood, cork, paper & Mr Jerald W. Richards & M & $5-8-2013$ & CFO & 680.530 & USA \\
\hline 102 & $\begin{array}{l}\text { RESORTS } \\
\text { QUINTILES } \\
\text { TRANSNATIONAL }\end{array}$ & Other services & Mrs Diane M Morefield & $\mathrm{F}$ & $9-3-2010$ & CFO & 2.406 .417 & USA \\
\hline M102 & HOLDINGS & Other services & Mr Kevin Gordon & M & $2-8-2010$ & CFO & 2.499 .153 & USA \\
\hline 103 & MULTI COLOR & Publishing, printing & Ms Sharon Eileen Birkett & $\mathrm{F}$ & $9-7-2010$ & CFO & 839.550 & USA \\
\hline M103 & $\begin{array}{l}\text { MEDIA GENERAL } \\
\text { QUANTUM }\end{array}$ & Publishing, printing & Mr James F. Woodward & M & $26-5-2011$ & CFO & 773.421 & USA \\
\hline 104 & CORPORATION & Machinery, equipment, furniture, recycling & Mrs Linda M. Breard & $\mathrm{F}$ & $11-1-2011$ & CFO & 369.593 & USA \\
\hline M104 & $\begin{array}{l}\text { SILICON GRAPHICS } \\
\text { INTERNATIONAL }\end{array}$ & Machinery, equipment, furniture, recycling & Mr Robert J. Nikl & M & $30-4-2012$ & CFO & 407.853 & USA \\
\hline 105 & BEBE STORES & Wholesale $\&$ retail trade & Mrs Liyuan Woo & $\mathrm{F}$ & $30-4-2013$ & CFO & 344.816 & USA \\
\hline M105 & PCM & Wholesale \& retail trade & Mr Steve Geiser & $\mathrm{M}$ & 19-11-2012 & CFO & 365.735 & USA \\
\hline
\end{tabular}


Notes with Appendix B:

$\mathrm{M} \# \#$ is the matched announcement regarding CEO/CFO turnover

CEO is for Chief Executive Officer, CFO is for Chief Financial Officer, $\mathrm{F}$ is for Female, $\mathrm{M}$ is for Male 
Appendix C - Global Gender Gap - Global Index

(source: World Economic Forum, 2016)

\begin{tabular}{|c|c|c|c|}
\hline Country & Index & Rank & HIGH - LOW \\
\hline Austria & .716 & 52 & $\mathrm{HIGH}$ \\
\hline Belgium & .745 & 24 & LOW \\
\hline Denmark & .754 & 19 & LOW \\
\hline Finland & .845 & 2 & LOW \\
\hline France & .755 & 17 & LOW \\
\hline Germany & .766 & 13 & LOW \\
\hline Greece & .680 & 92 & $\mathrm{HIGH}$ \\
\hline Ireland & .797 & 6 & LOW \\
\hline Italy & .719 & 50 & $\mathrm{HIGH}$ \\
\hline The Netherlands & .756 & 16 & LOW \\
\hline Norway & .842 & 3 & LOW \\
\hline Luxembourg* & .734 & 34 & - \\
\hline Sweden & .815 & 4 & LOW \\
\hline United Kingdom & .752 & 20 & LOW \\
\hline United States & .722 & 45 & $\mathrm{HIGH}$ \\
\hline Average & .760 & 27 & \\
\hline Weighted average & .743 & 34 & \\
\hline
\end{tabular}

Index is the score on the Gender Gap Index; rank is the rank on the Gender Gap Index. HIGH or LOW is decided on the basis of being above or below the weighted average rank (i.e, 34).

* Luxembourg is excluded from the HIGH-LOW classification as it exactly has the (weighted average rank), as a result, when comparing along this classification, we miss out on two announcements and total sample size is 198 (in the case of all announcements) and 98 (in the cases of the matches). 
Summary statistics for the average abnormal returns in the estimation window

\begin{tabular}{|c|c|c|c|c|c|c|c|c|c|}
\hline & \multicolumn{3}{|c|}{ Total sample } & \multicolumn{3}{|c|}{ Female sample } & \multicolumn{2}{|c|}{ Male sample } & \multirow{5}{*}{$\begin{array}{l}\text { Market } \\
\text { and risk } \\
\text { adjusted } \\
\text { returns }\end{array}$} \\
\hline & \multirow[b]{5}{*}{ alfa } & \multirow[b]{5}{*}{ beta } & \multirow{5}{*}{$\begin{array}{l}\text { Market } \\
\text { and risk } \\
\text { adjusted } \\
\text { returns }\end{array}$} & \multirow{4}{*}{\multicolumn{3}{|c|}{$\begin{array}{l}\text { Market } \\
\text { and risk } \\
\text { adjusted } \\
\text { returns }\end{array}$}} & \multirow[b]{5}{*}{ alfa } & \multirow[b]{5}{*}{ beta } & \\
\hline & & & & & & & & & \\
\hline & & & & & & & & & \\
\hline & & & & & & & & & \\
\hline & & & & alfa & beta & $(\%)$ & & & (\%) \\
\hline Mean return & -0.0001 & 0.9462 & 0.0000 & -0.0001 & 0.8695 & 0.0000 & -0.0001 & 1.0230 & 0.0000 \\
\hline Median & 0.0001 & 0.9113 & 0.0000 & 0.0001 & 0.8770 & 0.0000 & 0.0002 & 0.9316 & 0.0000 \\
\hline \multicolumn{10}{|l|}{ Standard } \\
\hline deviation & 0.0018 & 0.5175 & 0.0000 & 0.0020 & 0.4954 & 0.0000 & 0.0016 & 0.5300 & 0.0000 \\
\hline Minimum & -0.0127 & -0.4363 & 0.0000 & -0.0127 & -0.4363 & 0.0000 & -0.0066 & -0.2712 & 0.0000 \\
\hline Maximum & 0.0039 & 3.2888 & 0.0000 & 0.0039 & 2.0714 & 0.0000 & 0.0029 & 3.2888 & 0.0000 \\
\hline Skewness & -2.6584 & 0.6968 & -0.3011 & -3.1535 & 0.3020 & -0.4202 & -1.5904 & 1.0143 & -0.2256 \\
\hline Kurtosis & 14.0185 & 1.7431 & 1.3648 & 17.2153 & -0.0007 & 1.8978 & 4.4714 & 2.8494 & 1.0294 \\
\hline $\mathrm{N}$ & 200 & 200 & 200 & 100 & 100 & 100 & 100 & 100 & 100 \\
\hline
\end{tabular}




\section{Appendix E - Sensitivity analyses}

Panel A - Sensitivity Analysis for Relevant Press Releases in Event Window

This panel shows the (cumulative) average abnormal returns regarding the announcement of a CEO and in the case of relevant and non-relevant releases from the press respectively

AAR $t=-2$

AAR $t=-1$

AAR $t=0$

AAR $t=+1$

AAR $t=+2$

CAAR $[-2 ;+2]$

CAAR $[0 ;+1]$

CAAR $[-1 ;+1]$
0.0026

$-0.0012$

0.0020

$-0.0029$

0.0011

0.0004

$-0.0009$

0.0008

0.0003

$-0.0003$

0.0042

$-0.0025$

0.0002

$-0.0038$

0.0022

AAR is average abnormal return, CAAR is average abnormal returns; returns are estimated according to (1)-(4) in the main body of the paper. $t$ relates to the day in the event window; in brackets is the time window in days. Relevant press releases relate to press releases covering the announcement of other executives or board members and to press releases related to financial issues, such as financial results and dividend declarations. Non-relevant press releases do not include such information. 
Appendix E-continued

Panel B - Sensitivity Analysis for Insider/Outsider Status of Announced CEO/CFO

This panel shows the (cumulative) average abnormal returns regarding the announcement of the CEO or CFO being an insider or an outsider respectively.

\begin{tabular}{lcr} 
& Insider & Outsider \\
& & 106 \\
\hline AAR $t=-2$ & 0.0026 & 0.0014 \\
AAR $t=-1$ & 0.0015 & 0.0002 \\
AAR $t=0$ & -0.0014 & 0.0010 \\
AAR $t=+1$ & 0.0013 & -0.0024 \\
AAR $t=+2$ & 0.0009 & 0.0000 \\
CAAR $[-2 ;+2]$ & 0.0049 & 0.0002 \\
CAAR $[0 ;+1]$ & -0.0001 & -0.0015 \\
CAAR $[-1 ;+1]$ & 0.0013 & -0.0012
\end{tabular}

AAR is average abnormal return, CAAR is average abnormal returns; returns are estimated according to (1)-(4) in the main body of the paper. $t$ relates to the day in the event window; in brackets is the time window in days. An insider is defined as a person that has been working at the firm at which she is appointment. With an outsider, this has not been the case for the last five years. 
Appendix E - continued

Panel C - Sensitivity Analysis for CEO or CFO Function of Announced Executive

This panel shows the (cumulative) average abnormal returns regarding the announcement of a CEO and CFO respectively.

CEO

\begin{tabular}{lcr}
\hline & $N$ & 158 \\
\hline AAR $t=-2$ & 0.0010 & 0.0023 \\
AAR $t=-1$ & 0.0023 & 0.0005 \\
AAR $t=0$ & 0.0018 & -0.0008 \\
AAR $t=+1$ & -0.0001 & -0.0006 \\
AAR $t=+2$ & 0.0067 & -0.0012 \\
CAAR $[-2 ;+2]$ & 0.0117 & 0.0003 \\
CAAR $[0 ;+1]$ & 0.0017 & -0.0014 \\
CAAR $[-1 ;+1]$ & 0.0040 & -0.0009
\end{tabular}

AAR is average abnormal return, CAAR is average abnormal returns; returns are estimated according to (1)-(4) in the main body of the paper. $t$ relates to the day in the event window; in brackets is the time window in days. CEO relates to the newly announced top-executive being the chief executive officer; CFO relates to this person being the chief financial officer. 
Panel D - ANOVA-tests for Sensitivity Analysis of Total Sample of 200 firms at CAAR $[0 ;+1]$

\begin{tabular}{llll}
\hline & Relevant versus & Insider & CEO \\
& Not relevant & versus & versus \\
& press releases & Outsider & CFO \\
& $(1)$ & $(2)$ & $(3)$ \\
\hline F-value & 0.2600 & 0.0663 & 0.2523 \\
P-value & 0.6107 & 0.7971 & 0.6160 \\
\hline This table shows the test results of on ANOVA for three different subgroups. Source: Appendix D
\end{tabular}

This table shows the test results of on ANOVA for three different subgroups. Source: Appendix D

The first analysis (1) goes into the role of additional information where we distinct between relevant and nonrelevant press releases. A relevant press release is defined as a press release covering the announcement of other executives or board members and press releases related to financial issues, such as financial results and dividend declarations (69 events relate to relevant, 131 to not relevant press releases).

The second analysis (2) compares the impact of the news about whether the appointed CEO / CFO is an insider or an outsider. An insider is defined as a person that has been working at the firm at which she is appointment. With an outsider, this has not been the case for the last five years (106 events relate to insiders, 94 to outsiders).

The third analysis (3) compares the impact of the appointment of a CEO vis-à-vis a CFO (42 events relate to CEOs, 158 to CFOs). 


\section{Appendix F - International perspective}

These for panels report the (cumulative) average abnormal returns in countries which score higher (HIGH) or lower (LOW) than the weighted average rank on the Gender Gap Index (see Appendix C) and the differential between the two groups and the (cumulative) average abnormal returns in the US and elsewhere for all turnover announcements regarding CEOs and CFOs (Panel A), for the turnover announcement regarding male CEOs and CFOs (Panel B), for the turnover announcement regarding female CEOs and CFOs (Panel $\mathrm{C}$ ), and for the differential of the (cumulative) average abnormal returns (female minus male CEOs and CFOs) (Panel D) respectively.

$\mathrm{HIGH}-$

US-

HIGH LOW LOW

\begin{tabular}{|c|c|c|c|c|c|c|}
\hline \multicolumn{7}{|l|}{ Panel A-All } \\
\hline$N$ & 123 & 75 & & 100 & 100 & \\
\hline$A A R t=-2$ & 0.0026 & 0.0010 & 0.0016 & 0.0020 & 0.0023 & -0.0004 \\
\hline AAR $t=-1$ & 0.0019 & -0.0006 & 0.0024 & 0.0005 & 0.0012 & -0.0007 \\
\hline AAR $t=0$ & 0.0005 & -0.0024 & 0.0028 & 0.0009 & -0.0067 & 0.0025 \\
\hline AAR $t=1$ & 0.0020 & -0.0043 & 0.0063 & 0.0002 & -0.0010 & 0.0013 \\
\hline AAR $t=2$ & 0.0020 & -0.0022 & 0.0043 & 0.0020 & -0.0009 & 0.0028 \\
\hline CAAR $[-2 ;+2]$ & 0.0089 & -0.0085 & 0.0174 & 0.0056 & 0.0000 & 0.0055 \\
\hline CAAR $[0 ;+1]$ & 0.0024 & -0.0067 & 0.0091 & 0.0012 & -0.0026 & 0.0038 \\
\hline CAAR $[-1 ;+1]$ & 0.0043 & -0.0073 & 0.0115 & 0.0017 & -0.0014 & 0.0031 \\
\hline \multicolumn{7}{|c|}{ Panel B-Male } \\
\hline$N$ & 54 & 44 & & 50 & 50 & \\
\hline AAR $t=-2$ & 0.0013 & 0.0028 & -0.0015 & 0.0016 & 0.0022 & -0.0007 \\
\hline AAR $t=-1$ & -0.0011 & 0.0005 & -0.0016 & -0.0007 & -0.0003 & -0.0004 \\
\hline AAR $t=0$ & 0.0022 & -0.0026 & 0.0048 & 0.0021 & -0.0004 & 0.0025 \\
\hline AAR $t=1$ & 0.0021 & 0.0016 & 0.0005 & 0.0000 & 0.0032 & -0.0032 \\
\hline AAR $t=2$ & 0.0028 & 0.0058 & -0.0029 & 0.0033 & 0.0051 & -0.0018 \\
\hline CAAR $[-2 ;+2]$ & 0.0074 & 0.0082 & -0.0008 & 0.0063 & 0.0098 & -0.0036 \\
\hline CAAR $[0 ;+1]$ & 0.0043 & -0.0009 & 0.0052 & 0.0021 & 0.0028 & -0.0007 \\
\hline CAAR $[-1 ;+1]$ & 0.0032 & -0.0004 & 0.0036 & 0.0014 & 0.0025 & -0.0011 \\
\hline
\end{tabular}


HIGH-

US-

HIGH LOW LOW US non-US nonUS

Panel C-Female

N

AAR $t=-2$

AAR $t=-1$

AAR $t=0$

AAR $\mathrm{t}=1$

AAR $t=2$

CAAR $[-2 ;+2]$

CAAR $[0 ;+1]$

CAAR $[-1 ;+1]$
54

0.0035

0.0045

$-0.0004$

0.0017

0.0009

0.0102

0.018

$0.0058-0.0108$

44

$$
0.0011
$$

$-0.0002$

$-0.0022$

$-0.0078$
-0.0087 0.0096

0.0286

0.0119

0.0166
50

$\begin{array}{lll}0.0021 & 0.0023 & -0.0002\end{array}$

$\begin{array}{lll}0.0018 & 0.0027 & -0.0009\end{array}$

$\begin{array}{lll}-0.0001 & -0.0026 & 0.0025\end{array}$

$\begin{array}{lll}0.0003 & -0.0054 & 0.0057\end{array}$

$\begin{array}{lll}0.0005 & -0.0067 & 0.0072\end{array}$

$\begin{array}{lll}0.0046 & -0.0098 & 0.0143\end{array}$

$\begin{array}{lll}0.0002 & -0.0080 & 0.0082\end{array}$

$\begin{array}{lll}0.0020 & -0.0053 & 0.0073\end{array}$

Panel D Difference (Female - Male)

N

AAR $t=-2$

AAR $t=-1$

AAR $t=0$

AAR $t=1$

AAR $t=2$

CAAR $[-2 ;+2]$

CAAR $[0 ;+1]$

CAAR $[-1 ;+1]$
54

0.002

0.005

$-0.0024$

$-0.0007$

$-0.0020$

$0.0024-0.0265$

$-0.0031 \quad-0.0096$

$0.0025 \quad-0.0105$

44

$-0.0006$
$-0.0016 \quad 0.0036$

$\begin{array}{ll}-0.0009 & 0.0065\end{array}$

$-0.0019$

0.0083

0.0124

0.0289

0.0064

0.0130
50

$\begin{array}{lll}0.0004 & 0.0002 & 0.0002\end{array}$

$\begin{array}{lll}0.0026 & 0.0029 & -0.0003\end{array}$

$\begin{array}{lll}-0.0021 & -0.0024 & 0.0003\end{array}$

$\begin{array}{lll}0.0003 & -0.0084 & 0.0085\end{array}$

$\begin{array}{lll}-0.0029 & -0.0119 & 0.0089\end{array}$

$\begin{array}{lll}-0.0020 & -0.0196 & 0.0175\end{array}$

$\begin{array}{lll}-0.0021 & -0.0108 & 0.0087\end{array}$

$\begin{array}{lll}0.0005 & -0.0079 & 0.0084\end{array}$

AAR is average abnormal return, CAAR is average abnormal returns; returns are estimated according to (1)-(4) in the main body of the paper. $t$ relates to the day in the event window; in brackets is the time window in days. 


\section{References}

Abdullah, S. N., Ismail, K. N. I. K. and Nachum, L. (2016). Does having women on boards create value? The impact of societal perceptions and corporate governance in emerging markets. Strategic Management Journal, 37, 466-476.

Adams, R. B. (2016). Women on boards: The superheroes of tomorrow? The Leadership Quarterly, 27, 371-386.

Adams, R. B. and Ferreira, D. (2009). Women in the boardroom and their impact on governance and performance. Journal of Financial Economics, 94, 291-309.

Adams, R. B. and Funk, P. (2012). Beyond the glass ceiling: Does gender matter? Management Science, 58, 219-235.

Ahern, K. R. and Dittmar, A. K. (2012). The changing of the boards: The impact on firm valuation of mandated female board representation. Quarterly Journal of Economics, 127, 137-197.

Anderson, R. C., Reeb, D. M., Upadhyay, A. and Zhao, W. (2011). The economics of director heterogeneity. Financial Management, 40, 5-38.

Antonakis, J., Bendahan, S., Jacquart, P. and Lalive, R. (2010). On making causal claims: A review and recommendations. The Leadership Quarterly, 21, 1086-1120.

Antonakis, J., Bendahan, S., Jacquart, P. and Lalive, R. (2014). Causality and endogeneity: Problems and solutions. In: D.V. Day (ed.), Oxford Handbook of Leadership and Organizations. New York: Oxford University Press, 93-117.

Athey, S. and Imbens, G. W. (2017). The state of applied econometrics: Causality and policy evaluation. Journal of Economic Perspectives, 31, 3-32.

Beatty, R. P. and Zajac, E. J. (1987). CEO change and firm performance in large corporations: succession effects and manager effect. Strategic Management Journal, 8, 305-317.

Bernardi, R. A., Bosco, S. M. and Vassill, K. M. (2006) Does female representation on boards of directors associate with Fortune’s “100 Best Companies to Work For” list? Business \& Society, 45, 235-248. 
Binder, J. J. (1998). The event study methodology since 1969. Review of Quantitative Finance and Accounting, 11, 111-137.

Boehmer, E., Musumeci, J. and Poulsen, A. B. (1991). Event-study methodology under conditions of event-induced variance. Journal of Financial Economics, 30, 253-272.

Bohnet, I., Geen, A. van and Bazerman, M. (2016). When performance trumps gender bias: Joint vs. separate evaluation. Management Science, 62, 1225-1234.

Bonnier, K.-A. and Bruner, R. F. (1989). An analysis of stock price reaction to management change in distressed firms. Journal of Accounting and Economics, 11, 95-106.

Brown, S. J. and Warner, J. B. (1985). Using daily stock returns: The case of event studies. Journal of Financial Economics, 14, 3-31.

Campbell, C. J., Cowan, A. R. and Salotti, V. (2010). Multi-country event-study methods. Journal of Banking and Finance, 34, 3078-3090.

Campbell, K. and Mínguez-Vera, A. (2008). Gender diversity in the boardroom and firm financial performance. Journal of Business Ethics, 83, 435-451.

Carpenter, M. A. and Sanders, W. M. G. (2002). Top management team compensation: the missing link between CEO pay and firm performance. Strategic Management Journal 23(4): 367-375.

Carter, D. A., Simkins, B. J. and Simpson, W. G. (2003). Corporate governance, board diversity, and firm value. Financial Review, 38, 33-53.

Carter, D. A., D’Souza, F., Simkins, B. J. and Simpson, W. G. (2010). The gender and ethnic diversity of US boards and board committees and firm financial performance. Corporate Governance: An International Review, 18, 396-414.

Chapple, L. and Humphrey, J. E. (2014). Does board gender diversity have a financial impact? Evidence using stock portfolio performance. Journal of Business Ethics, 122, 709-723.

Chava S. and Purnanandam A. (2010). CEOs versus CFOs: incentives and corporate policies. Journal of Financial Economics, 97, 263-278.

Cook, T. D. (2008). "Waiting for life to arrive": A history of the regression-discontinuity design in psychology, statistics and economics. Journal of Econometrics, 142, 636-654. 
Cornelli, F., Kominek, Z., and Ljungqvist, A. (2013). Monitoring managers: Does it matter? Journal of Finance, 68, 431-481.

Corrado, C. J. (1989). A nonparametric test for abnormal security-price performance in event studies. Journal of Financial Economics, 23, 385-395.

Croson, R. and Gneezy, U. (2009). Gender differences in preferences. Journal of Economic Literature, 57, 225-245.

Dedman, E. and Lin, S. W. J. (2002). Shareholder wealth effects of CEO departures: Evidence from the UK. Journal of Corporate Finance, 8, 81-104.

Demsetz, H. (1983). The structure of ownership and the theory of the firm. Journal of Law and Economics, 26, 375-390.

Denis, D. J. and Denis, D. K. (1995). Performance changes following top management dismissal. The Journal of Finance, 50, 1029-1057.

Dezsö, C. L., Ross, D. G. and Uribe, J. (2016). Is there an implicit quota on women in top management? A large-scale sample statistical analysis. Strategic Management Journal, 37, 98115.

Faccio, M., Marchica, M.-T. and Mura, R. (2016). CEO gender, corporate risk-taking, and the efficiency of capital allocation. Journal of Corporate Finance, 39, 193-209.

Fama, E. F. (1970). Efficient capital markets: A review of theory and empirical work. Journal of Finance, 25, 383-417.

Fama, E. F. (1991). Efficient capital markets: II. Journal of Finance, 46, 1575-1617.

Fama, E. F. (1995). Random walks in stock market prices. Financial Analysts Journal, 51, 75-80.

Fama, E. F., Fisher, L., Jensen, M. C. and Roll, R. (1969). The adjustment of stock prices to new information. International Economic Review, 10, 1-21.

Francoeur, C., Labelle, R. and Sinclair-Desgagné, B. (2008). Gender diversity in corporate governance and top management. Journal of Business Ethics, 81, 83-95.

Furtado, E. P. and Rozeff, M. S. (1987). The wealth effects of company initiated management changes. Journal of Financial Economics, 18, 147-160. 
Golding, C. (2014). A grand gender convergence: Its last chapter. American Economic Review, 104, 1091-1119.

Gore, A. K., Matsunaga S. and Yeung, P.E. (2011). The role of technical expertise in firm governance structure: evidence from chief financial officer contractual incentives. Strategic Management Journal, 32, 771-786.

Hambrick, D. (1995). Fragmentation and the other problems CEOs have with their top management teams. California Management Review, 37, 110-127.

Haslam, S. A. and Ryan, M. K. (2008). The road to the glass cliff: Differences in the perceived suitability of men and women for leadership positions in succeeding and failing organizations. The Leadership Quarterly, 19, 530-546.

Hermalin, B. E. and Weisbach, M. (1998). Endogenously chosen boards of directors and their monitoring of the CEO. American Economic Review, 88, 96-118.

Hermalin, B. E. and Weisbach, M. (2003). Board of directors an endogenously determined institution: a survey of the economic literature. Economic Policy Review of the Federal Reserve Bank of New York, 9, 7-26.

Hillman, A. J., Canella Jr., A. A. and Harris, I. C. (2002). Women and racial minorities in the boardroom: How do directors differ? Journal of Management, 28, 747-763.

Huang, J. and Kisgen, D. J. (2013). Gender and corporate finance: Are male executives overconfident relative to female executives? Journal of Financial Economics, 198, 822-839.

Huson, M. R., Malatesta, P. H. and Parrino, R. (2004). Managerial succession and firm performance. Journal of Financial Economics,74, 237-275.

Ioannou, I. and Serafeim, G. (2012). What drives corporate social performance? The role of nationlevel institutions, Journal of International Business Studies, 34, 834-864.

Jensen, M. C. (1978). Some anomalous evidence regarding market efficiency. Journal of Financial Economics, 6, 95-101.

Johnson, J. L. (1996). Boards of directors: A review and research agenda, Journal of Management, 22, 409-438. 
Khan, W. A. and Vieito, J. P. (2013). CEO gender and firm performance. Journal of Economics and Business, 67, 55-66.

Lee, P. M. and James, E. H. (2007). She'-E-Os: Gender effects and investor reactions to the announcements of top executive appointments. Strategic Management Journal, 28, 227-241

MacKinlay, A. C. (1997). Event studies in economics and finance. Journal of Economic Literature, 35, 3-39.

Niederle, M., Segal, C. and Vesterlund, L. (2013). How costly is diversity? Affirmative action in light of gender differences in competitiveness. Management Science, 59, 1-16.

Niño, J. and Romero, P. J. (2007). How the change of CEO affects Chilean companies' stock returns. Latin American Business Review, 8, 37-64.

Pessarossi, P. and Weill, L. (2012). Does CEO Turnover Matter in China? Evidence from the Stock Market. BOFIT Discussion Papers, 21.

Post, C. and Byron, K. (2015). Women on boards and firm financial performance: A meta-analysis. Academy of Management Journal, 58, 1546-1571.

Reinganum, M. R. (1985). The effect of executive succession on stockholder wealth. Administrative Science Quarterly, 30, 46-60.

Roscoe, P. (2014). I Spend Therefore I Am. How Economics Has Changed the Way We Think and Feel. Toronto, Random House Canada.

Sedláček, T. (2011). Economics of Good and Evil. New York and Oxford, Oxford University Press.

Simpson, W. G., Carter, D. A. and D’Souza, F. (2010). What we know about women on boards. Journal of Applied Finance, 20, 27-39.

Terjesen, S., Sealy, R. and Singh, V. (2009). Women directors on corporate boards: A review and research agenda. Corporate Governance: An International Review, 17, 320-337.

Wang, M. and Kelan, E. (2013). The gender quota and female leadership: Effects of the Norwegian gender quota on board chairs and CEOs. Journal of Business Ethics, 117, 449-466.

Warner, J. B., Watts, R. L. and Wruck K. H. (1988). Stock prices and top management changes. Journal of Financial Economics, 20, 461-492. 
Weisbach, M. S. (1988). Outside directors and CEO turnover. Journal of Financial Economics, 20, $431-460$

Wessels, R. E., Wansbeek, T. and Dam, L. (2017). What is the relation (if any) between a firm's corporate governance arrangements and its financial performance? Multinational Finance Journal, forthcoming.

World Economic Forum (2016). Gender Gap Report 2016. Cologne and Geneva, World Economic Forum. 


\section{Table 1}

\section{Descriptive statistics of the sample}

Panel A - Firm characteristics (200 firms)

\begin{tabular}{lccc} 
& $\begin{array}{c}\text { Total assets (USD } \\
\text { million, 2013) }\end{array}$ & $\begin{array}{c}\text { Operating revenue } \\
\text { (USD million, 2013) }\end{array}$ & $\begin{array}{c}\text { Number of employees } \\
(2013)\end{array}$ \\
\hline Average & 33,700 & 8,773 & 24,417 \\
Median & 3,992 & 2,561 & 6,000 \\
Standard deviation & 220,512 & 18,528 & 55,567 \\
Minimum & 12 & 38 & 18 \\
Maximum & $2,415,689$ & 112,298 & 434,246
\end{tabular}

Panel B - Composition (distribution of the sample of 200 firms over industries, years, countries)

\begin{tabular}{|c|c|c|c|c|c|}
\hline Industry & $\%$ & Year & $\%$ & Country & $\%$ \\
\hline Banks & 3.8 & 2004 & 0.5 & Austria & 1.0 \\
\hline Chemicals & 6.7 & 2005 & 1.9 & Belgium & 1.9 \\
\hline Construction & 1.0 & 2006 & 1.0 & Denmark & 1.4 \\
\hline Food & 4.3 & 2007 & 1.0 & Finland & 1.9 \\
\hline Hotels & 1.9 & 2008 & 1.4 & France & 3.8 \\
\hline Insurance & 3.3 & 2009 & 1.9 & Germany & 5.7 \\
\hline Machinery & 15.7 & 2010 & 12.4 & Greece & 1.4 \\
\hline Metals & 1.0 & 2011 & 24.8 & Ireland & 1.9 \\
\hline Other & 20.0 & 2012 & 29.5 & Italy & 1.0 \\
\hline Primary products & 2.9 & 2013 & 23.8 & Luxembourg & 1.0 \\
\hline Publishing & 5.2 & 2014 & 1.9 & Netherlands & 1.9 \\
\hline Telecom & 5.7 & & & Norway & 1.4 \\
\hline Textiles & 1.0 & & & Sweden & 10.0 \\
\hline Transport & 4.8 & & & UK & 5.2 \\
\hline Utilities & 4.8 & & & US & 60.0 \\
\hline Consumer goods & 12.9 & & & & \\
\hline Woods & 5.2 & & & & \\
\hline
\end{tabular}




\section{Table 2}

Average abnormal returns (AARs) of the announcement of CEO/CFO appointments for the total sample ( $\mathrm{N}=200 ; 100$ female appointments and 100 male appointments)

\begin{tabular}{lccc} 
Day & AAR $(\%)$ & Standardized cross- & Corrado's rank \\
& & sectional test (p-value) & test (p-value) \\
\hline-2 & 0.2058 & 0.3214 & 0.3523 \\
-1 & 0.0870 & 0.4938 & 0.6380 \\
0 & -0.0278 & 0.9370 & 0.7858 \\
+1 & -0.0483 & 0.3824 & 0.4659 \\
+2 & 0.0494 & 0.9004 & 0.8750 \\
\hline
\end{tabular}

AAR is average abnormal return; the tests are explained in Appendix A of the paper. Day relates to the day in the event window. 


\section{Table 3}

Difference in average abnormal returns (AARs) between the announcement of female and male CEO/CFO appointments (calculated as female minus male) ( $\mathrm{N}=100$ pairs)

\begin{tabular}{lccc} 
Day & difference in & Standardized cross- & Corrado's rank \\
& AARs $(\%)$ & sectional test (p-value) & test (p-value) \\
\hline-2 & 0.0309 & 0.8291 & 0.8924 \\
-1 & 0.2731 & 0.1606 & 0.2000 \\
0 & -0.2238 & 0.2390 & 0.1940 \\
+1 & -0.4201 & 0.4700 & 0.7823 \\
+2 & -0.7386 & 0.0763 & 0.1621 \\
\hline
\end{tabular}

AAR is average abnormal return; the tests are explained in Appendix A of the paper. Day relates to the day in the event window. 
Table 4

Cumulative average abnormal returns (CAARs) of top-executive appointments in the total sample

( $N=200 ; 100$ female and 100 male)

CAAR CAAR Standardized Corrado's rank test

window $\quad$ cross-sectional test $\quad$ (p-value)

(p-value)

\begin{tabular}{llll}
{$[-2 ;+2]$} & 0.2662 & 0.8366 & 0.8031 \\
{$[0 ; 1]$} & -0.0761 & 0.4777 & 0.4791 \\
{$[-1 ;+1]$} & 0.0109 & 0.7991 & 0.7592 \\
\hline
\end{tabular}

CAAR is average abnormal returns; returns are estimated according to (1)-(4) in the main body of the paper and test statistics according to Appendix A. In brackets is the time windows in days. 
Table 5

Difference in cumulative average abnormal returns (CAARs) between female and male CEO/CFO appointments (calculated as female minus male) ( $N=100$ pairs)

CAAR Difference Standardized Corrado's rank test

window in CAAR cross-sectional test (p-value)

(\%) (p-value)

\begin{tabular}{llll}
{$[-2 ;+2]$} & -1.0784 & 0.2314 & 0.4129 \\
{$[0 ; 1]$} & -0.6438 & 0.1575 & 0.2652 \\
{$[-1 ;+1]$} & -0.3707 & 0.6770 & 0.8654 \\
\hline
\end{tabular}

CAAR is average abnormal returns; returns are estimated according to (1)-(4) in the main body of the paper and test statistics according to Appendix A. In brackets is the time windows in days. 